promise position between a noncompensable regulation on the one hand, and a complete, traditional taking on the other..$^{56}$

Unquestionably, Pewee has raised significant and perplexing problems. Indeed, it has recently been called "the most important labor case of the year ..." 57 (emphasis supplied). Speculation about possible solutions aside, the problems certainly merit more detailed consideration than the rather cursory glances bestowed upon them in Pewee.

\title{
VERTICAL FORESTALLING UNDER THE ANTITRUST LAWS
}

Monopolies and restraints of trade have traditionally been thought of in terms of horizontal market power. A recent increase in the number of cases involving exclusive dealing arrangements, resale price maintenance, boycotting practices, tie-ins, certain forms of agency agreements and vertical integration has pointed up the necessity of defining the extent of vertical control permissible under the Sherman, ${ }^{2}$ Clayton ${ }^{2}$ and Federal Trade Commission Acts. ${ }^{3}$ A strong argument can be made that these forms of vertical forestalling ${ }^{4}$ can have adverse effects on free competition only when used as a method of exploiting horizontal monopoly power. The Supreme Court appears to have accepted this argument with respect to vertical integration in recent cases holding that vertical integration is not per se illegal. However, the use of intent and conspiracy doctrines in the integration cases seems to have extended the area of the illegality despite the rejection of a per se rule.

With respect to looser forms of vertical forestalling, the cases state an even broader prohibition. Resale price maintenance is clearly illegal per se, and group boycotts may also fall within the "per se" category. In the field of exclusive supply and tying contracts, the courts have also established broad rules of illegality although a flat ban has not been reached. The cases applying these broad rules have, however, generally involved horizontal market power suf-

${ }^{56}$ For a discussion of the differences between a regulation and a taking, see Governmental Seizure of a Business to Prevent Strike Caused Work Stoppages-Regulation or Taking, I9 Geo. Wash. L. Rev. 184 (I950).

s7 Frank, The United States Supreme Court: 1950-51, I9 Univ. Chi. L. Rev. I65, I67 (1952).

I 26 Stat. 209 ( 1890 ), as amended, I5 U.S.C.A. \$ I et seq. (I95I).

${ }^{2} 38$ Stat. 730 (IgI4), as amended, 15 U.S.C.A. $\$ 12$ et seq. (I95 $\mathrm{r}$ ).

${ }^{3} 38$ Stat. $7 \mathrm{I} 7$ (IgI4), as amended, I5 U.S.C.A. $\$ 4 \mathrm{I}$ et seq. (I95I).

"For the purposes of this comment, the phrase "vertical forestalling" will be used as a generic phrase covering vertical control in all its forms ranging from outright vertical integration on the one extreme to exclusive dealing contracts and resale price maintenance on the other. At common law, "forestalling" referred to the exclusion of goods or traders from a market. Schueller, The New Antitrust Illegality Per Se: Forestalling and Patent Misuse, $50 \mathrm{Col}$. L. Rev. 170, 176-79 (1950). With the exception of resale price maintenance, these forms of vertical control involve the exclusion of outsiders from a certain market. Hence, he phrase "vertical forestalling." 
ficient to hamper free competition even though not illegal under the antitrust laws as they are presently applied. Possibly, then, the scope of these rules may indicate a desire to circumvent "[n]iggardly interpretations [which] have robbed [the antitrust laws] of much of their efficacy"s rather than a desire to ban vertical forestalling as such. Having refused to outlaw horizontal monopoly except in its extreme forms, the courts appear willing to outlaw vertical control as a method of exploiting and expanding monopoly in the broader, economic sense. ${ }^{6}$ This thesis may be illustrated by intensive treatment of the vertical integration cases coupled with brief comments on the other methods of vertical control.

\section{$\mathrm{I}$}

Prior to I940 vertical integration had been condemned under the Sherman Act only where found to be an integral part of horizontal monopoly or where used as a means of extending horizontal control to new levels. It had the blessing of Justice Holmes, who felt that the integration of successive stages of production should not be condemned even when combined with an intent to monopolize. ${ }^{7}$ In United States v. Int'l Harvester Co. ${ }^{8}$ the courts found unlawful horizontal monopoly but did nothing about the vertical control present. Such integration was approved as inevitable and desirable in United States v. United States

\footnotetext{
5 Douglas, J., "dissenting" in Standard Oil Co. (Calif.) v. United States, 337 U.S. 293, 316 (I949).

"As used in this comment "monopoly" designates that degree of market power necessary to affect market price. The term "illegal monopoly" will denote that degree of monopoly power prerequisite to the existence of a violation of Section 2 of the Sherman Act.
}

7 United States v. Winslow, 227 U.S. 202, 218 (I9I3). Cf. United States v. United Shoe Mach. Co., 247 U.S. 32 (19I8).

${ }^{8}{ }_{214}$ Fed. 987 (D.C. Minn., I9I4), Io F. $2 d 827$ (D.C. Minn., I926), aff'd 274 U.S. 693 (1927). In the complaint, petition in Equity No. 624 (D.C. Minn., Igr2), the United States had charged defendants with bringing together 85 per cent of the nation's harvesting machinery manufacturers with the purpose of monopolizing such machinery and also extending their monopoly to other lines. Ibid., at 8-18. It was also charged that the original monopoly was actually used to extend to new fields, such as tilling machines and twine, ibid., at 18-30, that exclusive dealing contracts were used to entrench the monopoly power, ibid., at I9-2I, and that vertical extensions into lumber, steel and railroading were carried out with the intent of furthering defendants' monopolistic purposes, Ibid., at $3 \mathrm{I}-34$. The prayer for relief was in general terms, however, asking for a dissolution of the unlawful combination and an injunction against continuation of the unlawful practices. Ibid., at 42-44.

The decree, entered November 2, 1918, at first commanded that International Harvester be broken up into "three substantially equal . . . and independent corporations." It was later amended so that defendants were forced to divest themselves of two of their "lines" of machinery but were left with the bulk of their business intact. The supplemental relief asked by the United States, but denied by the Supreme Court, United States v. Int'l Harvester Co., 274 U.S. 693 (1927), also aimed only at horizontal dissolution. Thus there was at no time any lessening of International Harvester's vertical control with the sole exception that it was forbidden to have more than one agent in any one town or city. Steel, railroading, lumber, twine, non-harvesting farm implement manufacturing and exclusive supplying agreements were left untouched throughout despite the emphasis on vertical control in the complaint.

International Harvester at present still retains a vast amount of vertical integration. See Moody's Industrials I64 (195 I). 
Steel Corp. ${ }^{9}$ In United States v. Eastman Kodak Co., ${ }^{\mathrm{x}}$ vertical integration by a powerful monopoly, which had been using its control at the manufacturing and raw materials levels to acquire control of other levels of trade, was disapproved by the District Court; $;^{7 x}$ but vertical dissolution was not part of the relief, ${ }^{12}$ and a later construction of the decree stated that Eastman Kodak might engage in wholesaling and retailing where it did so "for the development of [its] business ... in good faith and not for the purpose of creating an unlawful monopoly." ${ }_{13}$ Dissolution of the illegal combination in United States $v$. American Tobacco $C_{0 .}{ }^{14}$ included only relatively unimportant vertical divestiture; ${ }^{15}$ and the more extensive vertical dissolution granted in Standard Oil Co. (N.J.) v. United States $^{16}$ was, in the opinion of one acute observer, "more by accident than by design."17

In United States v. Corn Products Refining Co., ${ }^{18}$ vertical integration by a

225 U.S. 4I Z (I920). See also Alexander Milburn Co. v. Union Carbide \& Carbon Corp., I5 F. 2 d 678 (C.A. 4th, I926); United States v. Keystone Watch Case Co., 218 Fed. 502, 508-510 (E.D. Pa., I9I5). In the Steel case, the government's complaint had stated that the threat of vertical integration by steel producers into the finished steel products field, and vice versa, was the efficient cause of the original combination. Petition in Equity (D.C. N.J., IgrI) at I 5-23. Vertical extension backward (e.g., to ore supplies) and forward (e.g., into tube, wire, rod, nail and bridge manufacturing) was complained of. Ibid., at 24-37. The prayer for relief asked for the separation of the individual corporations making up the combination, which would have involved extensive vertical dissolution, and also asked specifically for cancellation of certain leases through which United States Steel controlled a large percentage of the nation's iron ore supply. Ibid., at 67-69. Apparently the Justice Department's estimate of the value of vertical integration was quite different than that of the Supreme Court.

${ }^{10} 226$ Fed. 62 (W.D. N.Y., IgI5), 230 Fed. 522 (W.D. N.Y., IgI6), appeal dismissed 255 U.S. 578 (I92I).

II Ibid., 230 Fed. 522, 523.

12 The final decree, entered February I, I92I in the District Court for the Western District of New York, ordered Eastman to dispose of its Premo, Century-Folmer and Schwing camera manufacturing plants, its Artura brand of photographic paper and its Seed, Stanley and Standard brands of dry plates. It also forbade defendants from making exclusive supplying contracts with their dealers. However, other methods of vertical control were permitted so long as they were for a bona fide business purpose and there was no vertical dissolution.

${ }_{33}$ Construction of the I92I decree, entered January 10, 1929.

34 I64 Fed. 700, ro24 (S.D. N.Y., rg08), rev'd 22r U.S. I06 (IgIr); rgr Fed. 37I (S.D. NY., I9II).

15 Licorice paste, cigar store and tin foil companies were cut off from the three main manufacturing concerns into which the American Tobacco Company was divided. United States v. American Tobacco Co., IgI Fed. 37I, 4I7-3I (S.D. N.Y., I9II). However, warehouses were not so separated; and the individual defendants, who owned approximately $40 \%$ of the voting stock in each of the three principal successors to the Tobacco Trust, also owned between $34 \%$ and $44 \%$ of such stock in the "separate" licorice, foil and cigar store companies. Ibid., at $415-16$.

${ }^{16} 22 \mathrm{r}$ U.S. I (IgIr).

27 Hale, Vertical Integration, 49 Col. L. Rev. 921, 924 (1949).

${ }^{28} 234$ Fed. 964 (S.D. N.Y., I9z6). Defendant starch-glucose manufacturer went into the candy business in order to threaten candy makers (who it felt were not giving it "sufficient" business) with competition, ibid., at $982-84$; and also attempted to monopolize the glucose syrup business by raising its glucose price to other syrup manufacturers at the same time as it 
manufacturer with illegal horizontal power was denounced where used as a tool in an attempt to monopolize new levels. Vertical divestiture was an important part of the consent decree held valid in United.States v. Swift 80 Co. $^{\text {x9 }}$ but that case, like the Corn Products case, is restricted as precedent by the presence of illegal horizontal power and the finding that the integration was for the purpose of extending that power. In none of these early cases did the government attack vertical integration as such. As the frequent failure to include extensive vertical dissolution in the relief indicates, the attack was always on horizontal monopoly with vertical integration being attacked indirectly and only where it served as a method of extending horizontal power or was incident to such power.

Three of the Anthracite Cases, where defendant common carriers were split off from their "captive" coal mining interests, represent the only direct attack on vertical integration prior to $1940 . .^{20}$ In all three cases, however, defendants controlled large percentages of the total anthracite supply through their mine and railroad holdings. Also, in the two cases involving the least amount of market control, ${ }^{2 I}$ United States v. Lehigh Valley R. Co. ${ }^{22}$ and United States $v$. Reading Co.,3 the Supreme Court emphasized the long histories of illegal practices and evasions of the law, indicating that defendants were motivated by a desire to stifle competition in the entire anthracite market. Furthermore, the presence of specific statutory restrictions and the fact that defendants were common carriers may limit these cases to their particular facts. ${ }^{24}$

lowered its syrup price thus "squeezing" non-integrated syrup manufacturers. Ibid., at roo41008. In I934 the Court of Appeals for the Second Circuit sustained a complaint against the Aluminum Company of America in a treble damage suit based on a similar squeeze theory. Baush Machine Tool Co. v. Aluminum Co. of America, 72 F. 2d 236 (C.A. 2d, I934).

${ }^{19} 286$ U.S. IO6 (I932). Despite the fact that the original consent decree was entered in I920, the last vertical divestiture was not completed by defendant Swift \& Co. until I942. Consult 6 Toulmin, Anti-trust Laws $§ 28.24$ (I95I).

. ${ }^{20}$ United States v. Reading Co., 226 U.S. 324 (Igr2); United States v. Reading Co., 253 U.S. 26 (r920); United States v. Lehigh Valley R. Co., 254 U.S. 255 (I920).

${ }^{2 x}$ In the first Reading case, defendants controlled $75 \%$ of the total United States anthracite supply, United States v. Reading Co., 226 U.S. 324, 339 (I9I2); in Reading II $33 \%$, United States v. Reading Co., 253 U.S. 26, 53 (I920); and in the Lehigh case $20 \%$, United States v. Lehigh Valley R. Co., 254 U.S. 255, 259 (I920).

22254 U.S. 255 ( 1920 ).

${ }^{23} 253$ U.S. 26 (I920).

24 The long series of railroad merger cases, of which these cases are the culmination, have been said to be "in a class by themselves" on the basis that they involve large, naturally monopolistic public utilities whose activities must be more carefully watched than firms operating in a potentially competitive environment. Levi, The Antitrust Laws and Monopoly, I4 Univ. Chi. L. Rev. 153, I $_{57}$ (I947). See Thomsen v. Cayser, 243 U.S. 66, 85 (IgI7). These cases are also peculiar in that the vertical integration involved fell within the ban, not only of the Sherman Act, but also of the "Commodities Clause" of the Interstate Commerce Act, which forbids railroads to transport articles in which they have an interest. 34 Stat. 585 (Ig06), 49 U.S.C.A. \& I (8) (I929). See United States v. Reading Co., 253 U.S. 26, 60-63 (I920); United States v. Lehigh Valley R. Co., 254 U.S. 255, 266, 270 (r920). The first Reading case arose before the passage of the Commodities Clause. 
More recent decisions have followed the earlier pattern of condemning vertical integration only where it was associated with some form of monopoly power. In United States v. Pullman Co. ${ }^{25}$ defendants, who had acquired a complete monopoly of sleeping-car manufacturing and servicing in a "non-predatory fashion," were held to have violated the Sherman Act because the court found both an intent to monopolize and the exercise of exclusionary power by means of exclusive dealing arrangements, staggered long-term contracts, and retention of title to the cars with the requirement that railroads desiring to lease them must also buy Pullman servicing for the leased cars. The District Court's injunction required defendants to sell Pullman cars to railroads desiring to operate their own cars and to cancel the exclusive dealing and tie-in arrangements between Pullman and the railroads. ${ }^{26}$ More important, Pullman was ordered to divest itself of either the servicing or the manufacturing end of its business. ${ }^{27}$ Pullman chose to continue manufacturing and, with the approval of the Supreme Court, sold its servicing monopoly to a group representing ninety-five per cent of American railroads. ${ }^{28}$ Thus the case seems to say that vertical control, legal when exercised by non-monopolistic units (assuming that the railroads are not monopolistic, or at least that federal regulation prevents them from exercising monopoly power), is unlawful in the hands of an unregulated manufacturing monopoly which though complete was not actually found to be in violation of the antitrust laws.

In United States v. Neve York Great A \& P Tea Co., ${ }^{29}$ a criminal prosecution under the Sherman Act, defendant grocery store chain was convicted of a consummated conspiracy to monopolize and restrain trade. Affirming this conviction, the Court of Appeals for the Seventh Circuit referred to defendant's "monopoly power," $3 \circ$ but at the same time stated explicitly that defendant's size and extensive vertical integration were not illegal by themselves. ${ }^{3 I}$ The gist of the illegality seems to have been defendant's "abuse" of its power..$^{32}$ The abuses consisted mainly of the use of large size and extensive vertical integration to force price concessions from suppliers and to undercut competitors. ${ }^{33}$

2s 50 F. Supp. I23 (E.D. Pa., 1943).

${ }^{26}$ United States v. Pullman Co., 50 F. Supp. I23, I36-37 (E.D. Pa., I943).

${ }_{27}$ Ibid., and 53 F. Supp. 908 (E.D. Pa., 1944).

${ }^{8}$ United States v. Pullman Co., 64 F. Supp. ro8 (E.D. Pa., 1945-46), aff'd by an equally divided court without opinion 330 U.S. 806 (1947).

${ }_{29} 67$ F. Supp. 626 (E.D. Ill., 1946), aff'd I73 F. 2d 79 (C.A. 7th, 1949).

${ }^{30}$ Ibid., I73 F. 2d 79, 88. The finding that defendant's boycotting practices were illegal, ibid., at 87 , is evidence of the court's thinking on this point. Unilateral boycotting is not illegal unless the boycotter possesses dominant market power. See text and notes at notes $84-93$ infra.

${ }^{3 x}$ Tbid., 173 F. $2 d 79,82,87$ and 67 F. Supp. 626,676 .

32 Ibid., r73 F. 2d 79, 82, 87 .

${ }_{33}$ See Adelman, The A \& P Case: A Study in Applied Economic Theory, 63 Q. J. Econ. 238 (1949). 
Some of the abuses, e.g., boycotting and "forcing" its suppliers to violate the Robinson-Patman Act, ${ }^{34}$.may have been illegal in and of themselves; ${ }^{35}$ but others such as price-cutting and operating at low profit margins, definitely were not. All were illegal because they were part of a plan to abuse A \& P's market power by operating a "two-price" system (one for A \& P and a higher one for competitors) which had the inevitable effect of driving out competition. ${ }^{36}$ Thus the $A$ \& $P$ case involves intent as well as power. It stands for the condemnation of vertical integration by a frrm with great, although lawful, market power only where such integration is used as part of a conspiracy to establish and maintain a system that will drive out competitors.

In four recent decisions the Supreme Court has crystallized the rules banning vertical integration connected with the acquisition or exercise of horizontal monopoly power and at the same time has stated that vertical integration would be illegal even in certain cases where illegal monopoly power is absent. In United States v. Yellow Cab Co., 37 the Checker Cab Manufacturing Corp. and its principal stockholder had acquired control of various Pittsburgh, Chicago, Minneapolis and New York companies operating 100\%, 86\%, $58 \%$ and $15 \%$, respectively, of the licensed cabs in those four cities. ${ }^{38}$ The government's complaint, charging, inter alia, the formation of a conspiracy to exclude other cab manufacturers from supplying defendants' operating companies, was dismissed by the District Court. ${ }^{39}$ In an opinion by Justice Murphy the Supreme Court reversed, holding that if any "appreciable segment of interstate cab sales" had been preempted as a result of the conspiracy charged, both Sections $I$ and 2 of the Sherman Act were violated. ${ }^{\circ}$ Supplying replacements for defendants' 5,000 cabs was sufficient to meet this test, irrespective of the "amount of interstate commerce thus affected" or its "importance ... in relation to the entire amount of that type of commerce in the United States." ${ }_{4 \mathrm{I}}$ However, Yellow Cab could not be cited as establishing the "per se" illegality of vertical integration. Justice Murphy emphasized the government's charge that the "primary object" of the defendants' conspiracy was the restraint of interstate trade and that the integration was not "normal expansion to meet the demands of business" but was "a calculated purchase for control," 42 all of which seems to require a finding of specific intent.

Although the $Y$ ellow $C a b$ case apparently makes any vertical integration illegal provided a "specific intent" is involved, the end toward which the intent

${ }^{34} 49$ Stat. ${ }_{5} 26$ (1936), ${ }_{5}$ U.S.C.A. §§ I3, 212 (r95 I).

3s United States v. New York Great A \& P Tea Co., r73 F. 2d 79, 87-88 (C.A. 7th, 1949).

${ }^{36} \mathrm{Tbid}$. Cf. Schine Theatres v. United States, 334 U.S. Iro (r948), especially II9-20.

${ }^{37} 332$ U.S. 2 I8 (x947).

${ }^{8}$ Ibid., at 22I-24.

3969 F. Supp. I70 (N.D. Ill., I946).

49 United States v. Yellow Cab Co., 332 U.S. 218, 224-28 (I947).

4I Ibid., at 225-26.

$4^{2}$ Ibid., at $227-28$. 
must be specifically directed was not adequately defined. Any vertical integration involves an intent to exclude competitors from the trade between the integrating units. To make such intent to monopolize the trade inter se sufficient to establish the illegality of vertical integration between parties without substantial market control would, in effect, create a rule of per se illegality. Justice Murphy's citation of authority, however, gives some indication that the intent he referred to was an intent to achieve general market control in order to raise prices rather than merely to monopolize the trade inter se.43

The "appreciable segment" test does not serve as a substitute for the requirement of horizontal monopoly power which appeared in the earlier vertical integration cases. The facts of the $Y$ ellow $\mathrm{Cab}$ case, as stated by the Court, indicate that defendants held a monopoly position in at least two of the four cities where they operated cabs; 44 and in rejecting an argument that only nationwide restraints are illegal, Justice Murphy quotes language from Indiana Farmer's Guide Co. v. Prairie Farmer Co.45 to the effect that the market need not be nationwide if it has geographical or distributive significance..$^{6}$ Arguably this language requires a finding of horizontal market control before the integration will be illegal. The opinion, however, ignores the market power of the local cab operating companies. It is the national cab manufacturing market to which the appreciable segment test is applied; and in the cab manufacturing field CCM's small percentage of total production was only enough to avoid a de minimis requirement. ${ }^{47}$ Justice Murphy relied on Section I authorities outlawing unreasonable restraints "regardless of the amount of commerce affected," 48

43 Most of the authorites cited by Justice Murphy in his vertical integration discussion are Section I cases not at all smilar to the Yellow Cab case on their facts. See text and note at note 48 infra. In the crucial summary paragraph where the question of intent is brought in, Justice Murphy refers, in two specific page citations, to a long series of combination cases most of them involving railroad mergers. Since CCM was the sole continuous manufacturer of purpose built cabs in the United States, United States v. Yellow Cab Co., 80 F. Supp. 936, 943 (N.D. III., 1948), and since its local cab companies were (in three cases out of four) in a dominant market postion, United States v. Yellow Cab Co., 332 U.S. 2I8, 221-24 (I947), there could be some justification for analogizing the Yellow Cab integration to the illegal merger of semimonopolistic railroad systems. The two railroad cases referred to in which market control was least (and therefore most similar to Yellow Cab's) were United States v. Reading Co., 253 U.S. 26 (I920), and United States v. Lehigh Valley R. Co., 254 U.S. 255 (I920), where the Supreme Court emphasized the intent of the defendants to effect a general market restraint in anthracite (going far beyond the intent merely to monopolize inter se). See text and notes 22-23 supra. That these two cases, with their intent emphasis, were important in Justice Mirphy's analysis is indicated by the fact that his definition of intent is quoted from the Reading case. United States v. Yellow Cab Co., $33^{2}$ U.S. 218, 227-28 (1947).

14 United States v. Yellow Cab Co., 332 U.S. 2r8, 224 (1947).

45293 U.S. 268, 279 (1934).

${ }^{6}$ United States v. Yellow Cab Co., 332 U.S. 218, 226 (1947).

47 United States v. Yellow Cab Co., 69 F. Supp. I70, I74 (N.D. Ill., I946). See subsequent opinion at 80 F. Supp. 936, 94I (N.D. Ill., I948).

$4^{8}$ United States v. Yellow Cab Co., $33_{2}$ U.S. 2 I8, 225 (1947). Justice Murphy cited United States v. Socony-Vacuum Oil Co., 3I0 U.S. I50, 225 n. 59 (I940), and Apex Hosiery Co. v. Leader, 3 Io U.S. 469,485 (I940). On the page cited in the Socony opinion, Justice Douglas 
and apparently meant to equate the "any part" wording of Section 2 with this mere jurisdictional limitation by subsuming both under the appreciable segment test. 49 Hence, that test is a mere jurisdictional or de minimis requirement and not a substitute for the horizontal power requirement of the earlier integration cases.

Like the integration cases prior to the Yellow Cab decision, United States v. Paramount Pictures, ${ }^{50}$ involved the use of vertical integration by horizontal monopolists at one level to extend their power to another, in this case a conspiracy of movie producer-distributors moving into the exhibition field. The District Court felt that the essence of the illegality lay in the horizontal restraints and it failed to cut down defendants' vertical integration..$^{5 x}$ Disagreeing with this view and also with the government's contention that vertical integration was illegal per se, ${ }^{52}$ the Supreme Court set forth two tests for determining the illegality of vertical integration to be considered on remand; such integration would be illegal ( $x$ ) where it was motivated by a purpose to gain control of an appreciable segment of interstate commerce rather than by normal business needs, and (2) where it afforded, as part of a monopolistic undertaking, the power to exclude competitors in a relevant market area, coupled with a purpose to use that power..$^{s 3}$ The first of these tests was stated in words almost identical with those of the $Y$ ellow $C a b$ case, ${ }^{54}$ while the second follows the illegal monopoly integration cases previously discussed. The language offers no guidance as to whether the intent must be in terms of exclusion $(A \& P)$ or raising prices (Yellow $C a b$ ). The amount of horizontal monopoly power necessary for illegality under the second test is apparently illegal monopoly power. On remand, the District Court found that defendants' horizontal control had been "powerfully aided" and extended to the exhibition level by vertical integration, and that the integration was therefore illegal under Justice Douglas' second test, despite the lack of any wrongful intent. 55

makes a statement substantially equivalent to Justice Murphy's with respect to Section I, citing in support Montague \& Co. v. Lowry, r93 U.S. 38 (rgo4), Steers v. United States I92 Fed. I, 5 (C.A. 6th, I9II), and Patterson v. United States, 222 Fed. 599, 6I8-I9 (C.A. 6th, I9r5). The Montague case involved market control within a definite geographical area, but the Steers case (involving the produce of one farm) and the dictum from the Patterson case (condemning the restraint as to a single interstate sale) clearly require no more than a minimal amount of interstate commerce without reference to any geographical control. The Apex case merely states the same conclusion and cites the same page of the Socony case in support.

49 United States v. Yellow Cab Co., 332 U.S. 218,225 (1947).

${ }^{50} 334$ U.S. $13 x$ (1948). $\quad{ }^{52} 66$ F. Supp. 323 (S.D. N.Y., 1946).

52 United States v. Paramount Pictures, 334 U.S. r31, I68-74 (r948).

53 Tbid., at 174 .

54 The only authorities cited in support of the first test are the Reading and Lehigh cases relied upon by Justice Murphy in the Yellow Cab case. See note 43 supra.

${ }_{55}$ The court ordered all of defendants' theaters divested. 85 F. Supp. 88I, 893-95 (S.D., I949). 
In United States v. Columbia Steel Co..$^{6}$ the government challenged the legality of United States Steel's acquisition of a western fabricating company, Consolidated Steel Corp. United States Steel's admitted purpose was "to assure a market for plates and shapes produced at" its recently acquired plant in Geneva, Utah. ${ }^{57}$ Moving first under a Section I count, Justice Reed, speaking for a fivemember majority, stated that vertical integration was not a restraint illegal per se under the Sherman Act. ${ }^{8}$ Therefore, it must be shown to be unreasonable if it is to be illegal; and to be unreasonable it must either be accompanied by an unlawful specific intent as in the $Y$ ellow $C a b$ case or else so unreasonably restrict the opportunities of competitors to market their product that such intent can be inferred. ${ }^{59}$ Outlining the factors that must be considered in a determination of whether a particular "acquisition results in" an "unreasonable restraint" from which intent may be inferred, Justice Reed stated that the court would "look ... to the precentage of business controlled, the strength of the remaining competition ... the probable development of the industry, consumer demands, and other characteristics of the market." facts, he stated that the exclusion of United States Steel's competitors from Consolidated's three per cent share of the market for rolled steel was not an unreasonable restraint even though United States Steel had one-third to onehalf of the total rolled steel capacity in the western states. ${ }^{6 r}$ Nowhere does Justice Reed discuss the possibility that U.S. Steel's fifty per cent market control represented an unlawful monopoly making vertical integration by it unlawful under the second Paramount test. It seems certain that he believed that in certain market situations vertical integration could unreasonably restrain trade even though not connected with illegal horizontal market power or the kind of complete monopoly present in the Pullman case. Turning to specific intent, Justice Reed, apparently believing that United States Steel's purpose was limited to excluding competitors from the market inter se, found no specific - intent to impose an unreasonable restraint. ${ }^{62}$

${ }^{56} 334$ U.S. 495 (1948).

s7 Ibid., at 506.

59 Ibid., at 522, 525 .

$5^{8}$ Ibid., at $5^{21-23}$.

60 Ibid., at 527 .

${ }^{6} \mathrm{Ibid}$., at 505-6, 526-27. Mr. Justice Reed's interpretation of the facts is not without its weak points. To get his estimate of Consolidated's share of the steel market he ignored the difference between plates and shapes and the wider gauge rolled steel products (three-fourths of Consolidated's business being in the former). Had he distinguished plates and shapes from other rolled steel products, as did the four dissenters in the case, ibid., at 538 , Consolidated's share of the Western market would have been $13 \%$ instead of $3 \%$, ibid., at 509 , a considerable difference in considering whether the effect on competition was one of unreasonable restraint.

${ }^{62}$ Ibid., at 527. Certain factors in the Western steel market not brought to the Court's attention might well have changed the result on the intent side had they been known. Kaiser's Fontana, California, plates and shapes producing steel facilities were much closer to Consolidated's Los Angeles plant (the largest West Coast user of plates and shapes) than was Geneva. The total California steel plates and shapes capacity was $478,75^{\circ}$ tons of which Fontana represented 309,000. American Iron \& Steel Institute Directory of Iron \& Steel 
Since there was no illegality under Section $I$, it followed, according to Justice Reed, that there could be none under Section 2 unless an intent to monopolize could be shown. ${ }^{63}$ Employing the same evidence to show the lack of illegal intent under Sections I and 2, he stressed the long-continued decline in United States Steel's total share of national production. ${ }^{64}$ Further, he stated that the government-blessed purchase of Geneva, with an understanding that finishing facilities to absorb its production would be erected, made the Consolidated purchase mere normal business expansion (practically sanctioned in advance by the government) rather than an attempt to circumvent the law. ${ }^{65}$

Pointing out that specific intent need not be shown where unreasonable restraint has resulted from the parties' joint action, the opinion of the four dissenters is most concerned with what constitutes an unreasonable restraint, not with the specific intent issue. ${ }^{66}$ The minority considered United States Steel's horizontal market power too large and did not wish to see it extended vertically. Their conclusion seems to be that vertical integration of an appreciable segment of an industry is unreasonable whenever one of the integrating units has dominating market power. ${ }^{67}$

The Supreme Court's second opinion in the Yellow Cab case ${ }^{68}$ established that vertical integration not combined with unlawful horizontal monopoly cannot be proved illegal on an intent basis unless there is a showing of specific intent to do more than monopolize the market between the integrating units. Remanded for trial on the merits, the case again went against the government in the trial court. ${ }^{69}$ Proceeding without a jury, District Judge LaBuy said that sound business judgment rather than unlawful intent motivated CCM's integration with the cab operating companies controlled by defendants. ${ }^{\circ 0}$ Economic explanations for the activities of the defendants were considered by Judge LaBuy only as

Works of the United States and Canada $47^{8-80}$ (25th ed., 1948). With the closest other plates and shapes facilities being in Colorado, Texas and Washington, ibid., the Consolidated market was of extreme importance to Kaiser and United States Steel. These facts were not presented in the argument before the Supreme Court. Had they been presented, the Court's assumption that United States Steel President Fairless' statement that the purchase was to "assure a market for plates and shapes produced at Geneva," United States v. Columbia Steel Co., 334 U.S. 495, 506 (I948), indicated a normal business purpose might have been open to question. As it was, Fairless' statement comes perilously close to an admission that the purpose of United States Steel's purchase was to exclude competition, particularly Kaiser, and therefore possibly wrongful. See text and notes at notes $\mathrm{I}_{40-46}$ infra. Big Steel's purchase was followed by Kaiser's erection of its own fabricating facilities, possibly because without Consolidated it had no adequate markets. Had this been known, the intent question might have been resolved differently.

63 Ibid., at 532.

64 Ibid., at 532-33. $\quad{ }^{66}$ Ibid., at 534-40.

65 Ibid. $\quad{ }^{67}$ Ibid., at 539-40.

${ }^{68}$ United States v. Yellow Cab Co., $33^{8}$ U.S. $33^{8}$ (r949).

69 United States v. Yellow Cab Co., 80 F. Supp. 936 (N.D. Ill., I948).

70 Ibid., at $942-44$. 
they related to the intent of the defendants and not as a basis for deciding whether or not the restraints involved were unreasonable. As to the possibility that the integration so restrained trade in the sale of cabs that intent might be inferred, Judge LaBuy mentioned no further evidence and merely stated that no such restriction existed especially since the operating companies were subject to strict regulation by the local municipalities. ${ }^{7 x}$ On appeal, the Supreme Court affirmed on the basis of the failure to find unlawful intent. ${ }^{22}$

In dissent, Justice Black, joined by Justice Reed, asked how there could be a judgment of dismissal where there had not been a full consideration of whether the restraints were so unreasonable as to be unlawful regardless of intent.73 The majority opinion, apparently regarding Judge LaBuy's curt dismissal of this point sufficient, is silent on this matter. Apparently the whole Court agreed that the "monopoly" power resulting from CCM's position as the sole continuous builder of "purpose built" cabs"4 and the local monopolies of the operating companies was insufficient to invoke the rule that vertical integration is unlawful where combined with horizontal monopoly.

Several factors present in the Yellow Cab situation might have placed CCM in a position to "abuse" its vertical power. ${ }^{75}$ Vertical integration could have enabled CCM to evade municipal rate regulation of the local operating monopolies by inflating the rate base with overpriced cabs if it could convince the local regulators (as it did the District Court ${ }^{76}$ ) that CCM "purpose built" cabs were really different from converted stock cars and worth their extra price. The temptation to act in this manner was increased by the fact 'that CCM could thereby siphon any possible monopoly profits to itself rather than leaving them with partially owned operating companies ${ }^{77}$ where they would be shared with outsiders. If the government had been able to prove that CCM overpriced its cabs for the reasons just suggested, it might have argued that the overpricing was such an abuse of CCM's vertical control as to make that control unlawful under the Sherman Act. Nevertheless, the doubtful wisdom of using the Sherman Act to protect minority stockholders or to remedy the shortcomings of local public utility regulation may justify the Court's failure to consider these factors.

In summary, it is clearly established that vertical integration will be illegal 7x Ibid., at 94I, 944 .

72 United States v. Yellow Cab Co., 338 U.S. 338 (1949).

73 Tbid., at $342-44$.

74 United States v. Yellow Cab Co., 8 o F. Supp. 936, 943 (N.D. Ill., r948).

${ }_{75}$ The fact that CCM sold the large majority of its cabs to its four operating companies, rather than on the competitive market, indicates that its cabs may have been "overpriced," United States v. Yellow Cab Co., 80 F. Supp. 936, 94I (N.D. Ill., I948), a fact alleged and accepted by the Court in the first case. Trans. Rec. at I2, I7, ibid., 332 U.S. 218 (I947); ibid., 332 U.S. $218,224^{-25}$.

${ }^{76}$ United States v. Yellow Cab Co., 8o F. Supp. 936, 943-44 (N.D. Ill., 1948).

77 Ibid., at 940 . 
when used by the holder of illegal monopoly power at one level to squeeze competitors at another level or to extend monopoly control to new levels. The Columbia Steel case, foreshadowed by Pullman and $A \& P$, states that vertical integration can be illegal without the existence of illegal horizontal monopoly provided it actually results in an unlawful market restraint or else is accompanied by a specific intent to restrain trade, but it rejects the notion of per se illegality for vertical integration. The unreasonableness is to be measured in terms of the effect of the integration on the opportunities of competitors in the relevant market area, an analysis of the entire economic context of defendants' actions thus becoming essential to a determination of illegality. The Yellow $\mathrm{Cab}$ cases show that the specific intent required is not merely the intent to monopolize the trade inter se, but a broader intent, probably the intent to achieve some general market control. With only three cases yet decided by the Supreme Court in this area, two of them ultimately going against the government, it is not yet possible to state the tests for the illegality of vertical integration with greater precision or detail.

\section{II}

Most of the looser forms of vertical forestalling have been condemned in language more broadly prohibitive than that employed in the vertical integration cases. An exception to this generalization appears in the agency cases. Vertical control by means of agency agreements closely resembles actual integration both economically and legally..$^{8} \mathrm{~A}$ manufacturer owning its outlets may require them to deal with it exclusively and may set their resale prices. Similarly exclusive dealing and resale price maintenance arrangements, often illegal when concluded between independent enterprises, 79 are normally lawful when consummated between principal and agent. ${ }^{80}$

A possible exception to the rule that agency equals integration appears, however, in the patent monopoly field. In United States v. General Electric Co. ${ }^{8 \mathrm{x}}$ the Supreme Court allowed the holder of a patent to exercise vertical control over the wholesaling and retailing of its products, including the setting of resale prices, by means of a "bona fide" agency arrangement. But the General Electric case has been greatly restricted. In United States v. Masonile Corp., ${ }^{82}$ the Court struck down a series of agency agreements executed by patent holding manufacturer where it appeared that the firms involved were integrated competitors using the agency device as a guise for an industry-wide price fixing conspiracy. The Masonite case may be made consonant with the vertical integration precedents by interpreting it as involving a specific intent to control the market so that it restricts agency agreements only to the extent that $Y$ ellow $\mathrm{Cab}$ restricts

${ }^{78}$ Standard Oil Co. (Calif.) v. United States, 337 U.S. 293, 3ro, 320 (r949).

${ }^{79}$ See text and notes at notes ro4-25 infra.

${ }^{80}$ FTC v. Curtis Publishing Co., 260 U.S. 568 (I923) (exclusive agency contracts). See Dr. Miles Medical Co. v. Park \& Sons Co., 220 U.S. 373 (IgIr) (resale price maintenance).

${ }^{8 x} 272$ U.S. 476 ( $\left.\mathrm{r}_{926}\right)$.

${ }^{82} 316$ U.S. 265 (r942). 
vertical integration. A more severe limitation occurs in United States v. Line Material Co. which specifically limits the General Electric case to single patentees without regard to intent. ${ }^{83}$ Thus several independent patent monopolists may not combine to exercise the vertical control through agency agreements that they could exercise separately.

Boycott cases involve vertical forestalling where the defendants have used economic power on one level to coerce their competitors on other levels. In the cases involving a concerted refusal to deal, defendants typically possessed dominant market positions. There is language in Fashion Originators' Guild of Ameri$c a$ v. $F T C^{84}$ which can be interpreted as making a boycott by agreement illegal per se, ${ }^{85}$ but in that case the defendants controlled sixty per cent of the industry. "Monopoly power" was present in more attenuated form in Associated Press $\%$. United States, a more recent boycott case. ${ }^{86}$ That case, however, involved the largest of the only three nationwide newsgathering agencies, the lack of whose services was said by the opinion of the Supreme Court to be a definite competitive disadvantage to any urban daily paper; ${ }^{87}$ hence it can hardly be said that the defendants were without some monopoly power. In fact a boycott can hardly have any significant effect apart from coercive market power, and, barring certain non-economic motivation, can have utility only as a method for creating or exploiting a monopoly position..$^{88}$

Where there is refusal to deal by a single trader only, the few cases in point have held that illegality can follow only if that trader has dominant market power. ${ }^{89}$ Perhaps the most attenuated application of this doctrine occurs in a district court opinion, United States v. Klearflax Linen Looms. ${ }^{\circ}$ There, defendant, the only domestic manufacturer of linen rug material, attempted to monopolize, as against one of its own distributors, all sales to the federal govern-

${ }^{83} 333$ U.S. 287 (1948).

${ }^{84} 3{ }_{2}$ U.S. 457 (I94I).

${ }^{85}$ See Kirkpatrick, Commercial Boycotts as Per Se Violations of the Sherman Act, to Geo. Wash. L. Rev. 302, 387 (1942). The Supreme Court, in United States v. Columbia Steel Co. 334 U.S. $495,5^{22-23}$ ( 1948 ), stated that "where a complaint charges that the defendants have ... concertedly refused to deal with non-members of an association . . . such restraints [are] illegal per se." But cf. United States v. Women's Sportswear Ass'n, 336 U.S. 460 (I949), a case involving boycott activities carried on jointly by over one-half the stitchers of women's sportswear in the Boston area. There the Supreme Court pointed to both the wrongful intent and the restrictive effect of defendants' boycott in holding it to be in restraint of trade. Ibid., at 463 .

${ }^{86} 326$ U.S. I (1945).

${ }^{8} 7$ Ibid., at $\mathrm{I}_{3}$, I7-I8.

${ }^{88}$ Those boycotted could, without disadvantage to themselves, trade with the competitors of the boycotters unless the boycotters possessed some degree of market control. Moreover, it is hard to imagine what purpose a boycott can have except as an exclusionary measure, something not possible without considerable market power. See Chain-Store Integration as Restraint of Trade Under the Sherman Act, I5 Univ. Chi. L. Rev. 392, 393 (I948).

${ }^{89}$ FTC v. Raymond Bros.-Clark Co., 263 U.S. 565 (1924); Sorrentino v. Glen-Gery Shale Brick Corp., 46 F. Supp. 709 (E.D. Pa., I942). Cf. Eastman Kodak Co. v. Southern Photo Materials Co., 273 U.S. 359 (I927).

${ }^{\circ 0} 63$ F. Supp. 32 (D.C. Minn., I945). 
ment which bought one-third of the total output.9x The method used was first a refusal to deal with the distributor who bid against it on a government contract followed by demotion of the competing distributor to the status of a jobber (with accordingly higher prices). This was held to be a violation of Section 2 of the Sherman Act although there were product substitutes available and defendant's one million dollar annual production was less than one-half of one per cent of the total United States rug business. The Klearflax Company had acquired its "monopoly" through normal business methods rather than through predatory practices; and it existed "free from any wrongful domination, illegal combination, or wrongful destruction of the business of other competitive manufacturers." 22 Very slight extension of the Klearflax case would establish that the seller of trademarked items, or the seller of any product distinguishable by the public from its closest competitors could not use boycotting tactics in an effort to pre-empt any part of its market. However, the Klearflax holding may be qualified by the existence of a conspiracy between Klearflax and its other distributors ${ }^{93}$ which would make it a group boycott case. The cooperation of these other distributors was necessary to the execution of Klearflax's plan so that concert of action may have been a sine qua non of the illegality even though the opinion does not specifically so state. Thus boycotts appear to be illegal only when carried on by group action, or else by a single trader possessing some market control, and even the group action cases have all involved monopoly power.

Another group of cases involving attempts to bring two or more stages of production under a single control are "tie-in" cases under Section 3 of the Clayton Act. Here, too, illegality has resulted only in involving monopoly power situations, ${ }^{94}$ although language in recent cases would support a flat per se rule. Patentees attempting to force users of the patented article to use unpatented products as well have been held to have violated the Sherman and Clayton Acts, ${ }^{95}$ and in a recent Supreme Court case so holding, Int'l Salt Co. v. United States, ${ }^{96}$ the language would support a fiat ban on all tying (and exclusive dealing) agreements. Where no patent monopoly is involved, however, tie-ins have

$$
92 \text { Ibid., at 33-34. } 92 \text { Ibid. } 93 \text { Ibid., at 34-40. }
$$

94 Stocking \& Watkins, Monopoly and Free Enterprise $360-63$ (195I). According to these authors, tying contracts do not oppress competitors in all circumstances. "Doubtless such considerations influenced Congress in limiting the prohibition of ... tying contracts to circumstances in which 'the effect... may be to substantially lessen competition or tend to create a monopoly.' In what circumstances 'may' the effect specified reasonably be anticipated? Though it would be diffcult to frame a precise rule covering all cases, at least one condition appears to be a prerequisite: possession by the seller of monopolistic power over one or more of the products affected. An analysis of the cases supports this view." Ibid., at $36 \mathrm{r}$. Cf. Standard Oil Co. (Calif.) v. United States, 337. U.S. 293, 306 (I949); Miller, Unfair Competition $194-213$ (r94r).

95 Int'l Business Machines Corp. v. United States, 298 U.S. I3I (I936); United Shoe Mach. Corp. v. United States, 258 U.S. 45 I (I922).

${ }^{96} 332$ U.S. 392 (1947). 
been condemned in practice only where they were imposed by defendants in a powerful market position. In affirming the conviction of General Motors under Section I of the Sherman Act for tying-in financing with the sale of cars,97 the Court of Appeals for the Seventh Circuit emphasized the dominant market position of the defendant..$^{8}$ However, in Signode Steel Strapping Co. v. FTC,99 the Court of Appeals for the Fourth Circuit stated that a maker of wire parcelwrapping machines could not tie-in the wire with the machines of its business was substantial dollarwise regardless of its position in the relevant competitive market. The significance of this dictum is attenuated by the fact that the Federal Trade Commission order involved was one of three forbidding tie-ins by three firms doing over two-thirds of the total United States wrapping-machine business. ${ }^{x 00}$ Although this does not show Signode to have very great market power, the Fourth Circuit held that the evidence justified the FTC finding that the practices of these firms did substantially lessen competition. Furthermore, the dictum in the case has never been applied where those accused were not in a powerful market position, ${ }^{10 x}$ and in United States $v . J . I$. Case Co., ${ }^{102}$ a district court upheld the right of a large farm equipment company to require dealers to handle its full line of machines as a condition for obtaining a dealership contract. The court's consideration of tying is extremely brief and contains no discussion of the precedents; but the holding is a clear indication that tie-ins are not illegal, at least under the Clayton and Sherman Acts, in competitive situations where they are not the result of coercive practices. ${ }^{103}$

97 United States v. General Motors Corp., 121 F. 2 d 376 (C.A. 7th, 194r).

${ }_{98}^{8}$ Ibid., at 403. $\quad{ }_{99}^{132}$ F. 2 d 48,54 (C.A. 4th, 1942). $\quad{ }^{300}$ Ibid., at 50.

${ }^{20}$ The leading non-patent tie-in case sinceSignode is Judson L. Thompson Mfg. Co.v. FTC, I50 F. 2d 952 (C.A. Ist, I945). Defendant leased riveting machines on condition that its lessees use only defendant's rivets in the machines. Its leases covered one-third of the riveting machines in operation in the United States and its sales of rivets represented twenty per cent of the industry's sales. Ibid., at 953-54. Together with three other companies, defendant did about two-thirds of the total United States business in rivets and rivet machines. Ibid., at 954. The FTC's cease and desist order was upheld by the First Circuit on the bases that the facts were not materially distinguishable from those in the Signode case. Ibid., at 958 . Thus the court avoided commenting on the Signode dictum. That monopolistic elements were clearly present is shown in the court's statement that the tying clause gave defendant the power "to compel a substantial proportion of the market to use its rivets," a condition hardly compatible with effective competition. Ibid., at $95^{8}$.

${ }^{102}$ CCH Trade Reg. Rep. I 62,921 (D.C. Minn., I95I).

${ }^{103}$ The facts of the case are markedly similar to the Signode case. Defendant Case was the third largest "full line" farm equipment manufacturer, and tie-ins of the sort involved were "the pattern of the industry." Ibid., at $64,808,64,8$ I 5 . However, the court pointed out the competitive nature of the industry and found that the tie-ins were the result of "mutual agreements between the manufacturer and the dealers" rather than unilateral coercion by Case and that prohibiting them "might tend to discourage competition rather than to stimulate it." Ibid., at $64,8 \mathrm{r}_{4}-\mathrm{I}_{5}$. See text and notes at notes $\mathrm{r}_{23}-\mathrm{I} 25$ infra. Apparently District Judge Nordbye felt that coercion, a mark of market control, was a prerequisite to the illegality of tie-ins. In any case he did not believe in applying the broad language of the Signode case in all situations involving any substantial share of interstate commerce. 
Prior to the Miller-Tydings Amendment, ${ }^{\text {To4 }}$ resale price maintenance was a form of vertical control that apparently was held illegal in all cases. However, it is difficult to see how a manufacturer can sell a truly fungible, homogeneous product above the going price in a competitive market; hence resale price maintenance probably makes sense only where there is imperfect competition. It has been strongly urged that resale price maintenance is only useful to its originators in situations involving retail conspiracies, "brand name monopolies," or "signal-calling" by oligopolists. ${ }^{105}$ The earlier cases condemning resale price maintenance support this view since they involve, without exception, market power in the form of copyrights and patents ${ }^{206}$ or brand name monopolies. ${ }^{\text {xor }}$

Resale price maintenance has, of course, been partially legalized by the Miller-Tydings Amendment with respect to branded products. The limitation of the Amendment to branded products that are in competition with similar goods and to vertical agreements not involving the combination of competitors on any horizontal level ${ }^{\mathrm{ro8}}$ restricts the amount of monopoly power with which vertical resale price control may be connected under the Amendment. However, cases decided since the passage of the Amendment have condemned resale price maintenance, not immunized by the Amendment, as a per se violation of the Sherman Act. ${ }^{\mathrm{Tog}}$ Kiefer-Stewart v. Seagram \&o Sons ${ }^{\mathrm{II0}}$ finds a conspiracy to fix maximum resale prices illegal even where no market power, restraining effect

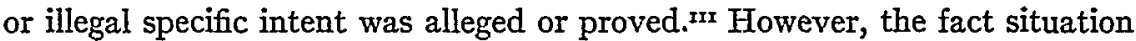

${ }^{204} 50$ Stat. 693 (1937), $x_{5}$ U.S.C.A. \& I (195I).

ros See The Per Se Illegality of Price-Fixing: Sans Power, Purpose or Effect, to be printed in Ig Univ. Chi. L. Rev. No. 4 (I952). The primary justification advanced in favor of resale price maintenance has been that it protects a product's reputation, especially by preventing "loss leader" selling. American Fair Trade Council, Resale Price Maintenance 3-6 (I942). However, a manufacturer's reputation can hardly be damaged by low prices unless it is assumed that the buying public is so irrational as to prefer higher priced goods in certain fields. See Resale Price Maintenance and the Anti-Trust Laws, I8 Univ. Chi. L. Rev. 369, 379 (x95I). Those damaged by the loss leadership selling are the retailers who do not themselves engage in loss leading. The resale price maintenance system is essentially a bargain between manufacturer and retailer whereby the manufacturer agrees to maintain standard prices and a high mark-up in return for the retailer's efforts in pushing his product while putting competitive items without similar price maintenance "under the counter." Such a system could only exist on the assumptions (I) that each retailer has a monopoly position with respect to his own customers enabling him to sell the high mark-up brands, and (2) that horizontal power on the part of all the retailers will keep price cutters out of the retail field.

${ }^{106}$ E.g., Bobbs-Merrill Co. v. Straus, 2I0 U.S. 339 (Ig08); Bauer v. O'Donnell, 229 U.S. I (IgI3); Boston Store v. American Graphophone Co., 246 U.S. 8 (Igr8); United States v. Schrader's Son, Inc., $25^{2}$ U.S. 85 (I920).

${ }^{107}$ E.g., Dr. Miles Medical Co. v. Park \& Sons Co., 220 U.S. 373 (191I); FTC v. BeechNut Packing Co., 257 U.S. 44I (rg22).

${ }^{{ }^{08}}$ See United States v. Frankfort Distilleries, Inc., 324 U.S. 293 (r945).

${ }^{109}$ E.g., ibid.; United States v. Bausch \& Lomb Optical Co., 32I U.S. 707 (I944); United States v. Univis Lens Co., 3 I 6 U.S. 24 I (I942).

${ }^{\text {r10 }}$ I82 F. 2 d 228 (C.A. 7th, I95I), rev'd 340 U.S. 2 II (I95I).

${ }^{x x}$ See the trial court's instructions to the jury. Trans. Rec. at 267 , Kiefer-Stewart v. Seagram \& Sons, 340 U.S. 2 I I (r95I); The Per Se Illegality of Price-Fixing: Sans Power, Purpose or Effect, to be printed in 19 Univ. Chi. L. Rev. No. 4 (1952). 
underlying the Kiefer-Stewart case clearly involved monopoly power and it does not, therefore, detract from the view that resale price maintenance will be practiced only under conditions of imperfect competition. ${ }^{\mathrm{In}}$

Another possible exception to the thesis that vertical forestalling can be condemned only in connection with monopoly power appears in the area of exclusive supply contracts. Prior to I 948 such contracts had been condemned, in proceedings arising primarily under Section 3 of the Clayton Act, only when pursued by defendants dominant in the relevant market areas. ${ }^{\mathrm{Ir} 3}$ However, in Standard Oil Co. (Calif.) v. United States, this limitation was expressly removed by the Supreme Court. ${ }^{\text {Irt }}$ The opinion, by Justice Frankfurter, implied the removal of the limitation with respect to tie-in contracts as well (thus tacitly approving the dicta of the International Salt and Signode cases). ${ }^{\text {xs }}$ The sole proviso was that a "substantial" amount of interstate commerce be involved, a requirement implying little more than a jurisdictional or "de minimis" requirement ${ }^{\text {t16 }}$ similar to the appreciable segment test in the integration cases.

The Standard Stations case, like the tie-in cases, can be distinguished from a per se condemnation of vertical control as such. It was brought against a firm during twenty-three per cent of the business in the relevant market area ${ }^{117}$ in an industry controlled largely by a few major suppliers whose collective (although not collusive) use of these exclusive supplying contracts very probably, in the view of Justice Frankfurter, had the effect of maintaining their dominant position and deterring new entry into the industry. ${ }^{\mathrm{rr} 8}$ Two recent District Court opinions indicate the lines along which limitations on the scope of the Standard Stations holding may develop. United States v. Richfield Oil Corp. ${ }^{\mathrm{x} 9}$ extends the holding of the Standard Stations case to Section I of the Sherman Act and finds illegality in the requirements contracts of a oil company defendant operating in the same area as Standard of California but not having the economic power of that company. Still, Richfield is one of the major firms in an industry dominated by large integrated firms ${ }^{120}$ who have recently been under

xx Ibid.

${ }^{213}$ See Standard Oil Co. (Calif.) v. United States, 337 U.S. 293, 300-304 (1949); Miller, Unfair Competition 203- $\mathrm{r} 3$ (I94I).

$$
{ }^{2 x 4} 337 \text { U.S. } 293 \text { (1949). } \quad \text { Irs Ibid., at 304-305, } 314 .
$$

${ }^{116}$ There is no indication in the case that anything more than interstate movement plus volume sufficient to be more than de minimis is necessary. Ibid., at 295-97, 314. See Int'l Salt Co. v. United States, 332 U.S. 392, 395-96 (r947). Consult District Judge Yankwich's discussion of this point in the lower court. United States v. Standard Oil Co. (Calif.), $78 \mathrm{~F}$. Supp. 850, 866-67 (S.D. Calif., I948).

${ }^{137}$ Standard Oil Co. (Calif.) v. United States, 337 U.S. 293, 295 (I949).

s18 Ibid., at 309 .

${ }^{119} 99$ F. Supp. 280 (S.D. Calif., r95r).

${ }^{\text {r20 }}$ Richfield, sixty-two per cent of whose stock is owned by Cities Service and Sinclair, Moody's Industrials r874-75, I 998 (I95I), is one of the West Coast's "Big Seven" (the others besides Standard of California are Texaco, Shell, Tidewater Associated, General Petroleum and Union Oil). Their combined production totals over two-thirds of the West Coast consump- 
attack by the government for joint violations of the Sherman and Clayton Acts. ${ }^{\text {22I }}$ Moreover, the court speaks of Richfield's "coercive" tactics in maintaining the exclusive supplying arrangements. ${ }^{22}$ The question of coercion was further analyzed in United States v. J. I. Case Co. ${ }^{\mathrm{x} 23}$ Defendant Case Co. was the third largest "full line" farm equipment manufacturer whose \$I07,000,000 gross represented $7 \%$ of the nation's total farm equipment business in I948. One-third of Case's dealers handled only Case products although this was not required by their dealership contracts. ${ }^{125}$ The government's bill, asking that Case be enjoined from using exclusive dealing arrangements, was dismissed by the district court. Distinguishing the Standard Stations case, the court found that the exclusive dealing arrangements which existed were the result of mutual agreement as to the best method of carrying on the business, that Case's policy was against "coercing" dealers into accepting them, and that the farm equipment business was highly competitive. Thus the difference in result between the $J$. I. Case and Richfield cases seems to turn largely on the contrast between coercion and mutual agreement dictated by sound business judgment. If the presence of the power to coerce dealers into accepting exclusive dealing arrangements is equivalent to some form of market control, these two cases are a definite indication that exclusive dealing sans monopoly is not unlawful. In any case, the J. I. Case holding is a refusal to treat Standard Stations as a flat per se precedent.

In summary, most of the "loose" vertical forestalling cases are more stringent than the vertical integration cases and there is even per se illegality, or something approaching it, in certain types of cases. Even in the agency situation, which is most like vertical integration, there is doubt as to the legality of vertical control by a patentee, the possessor of specifically sanctioned monopoly power. Clearly a patentee may not exercise vertical control via agency arrangements if those arrangements are the result of agreement between two patentees. In unilateral boycott cases, the existence of monopoly power is a prerequisite to illegality; but it is not clear that the degree of monopoly power must be unlawful, as is required for in integration cases under the second Paramount test.

An even broader rule of illegality, approaching a flat per se ban, seems to be developing in the group boycott cases. Such a per se rule might be explained on

tion of petroleum products and they all use exclusive supplying arrangements similar to Richfield's. Standard Oil Co. (Calif.) v. United States, 337 U.S. 293, 295 (I949). Richfield's total business in r950 was over $\$ 40,000,000$, United States v. Richfield Oil Corp., 99 F. Supp. 280, 285-86 (S.D. Calif., 1951), not too far short of the $\$ 66,000,000$ total for Standard of California in the Standard Stations case. Standard Oil Co. (Calif.) v. United States, 337 U.S. 293, 295-96 (1949).

${ }^{131}$ Civil Action No. Ir584-C (S.D. Calif., 1950). See CCH Trade Reg. Rep. ๆ61,265.

United States v. Richfield Oil Corp., 99 F. Supp. 280, 293-96 (S.D. Calif., I95I).

${ }_{123}$ CCH Trade Reg. Rep. If 62,92I (D.C. Minn., I95I).

224 Ibid., at 64,808.

125 Ibid. 
the basis that vertical forestalling was being condemned only where connected with monopoly power since it is hard to see why group boycotting would ever be complained of where the boycotters possessed no market power. Much the same thing can be said about the per se rule developed in the resale price maintenance cases. There too the restraints in question seem to make little sense unless exercised by those possessing significant market power.

The longest step toward per se illegality involving non-monopolistic situations has been taken in the tying and exclusive supplying cases arising primarily under Section 3 of the Clayton Act. However, the J. I. Case decision indicates that the sweeping prohibitions enunciated by the courts in the Standard Stations, Signode and Richfield cases may be limited to situations where the users of vertical control possess coercive market power.

\section{III}

Concepts important in both "loose" and "close" vertical forestalling cases were applied and expanded in a recent Seventh Circuit case, United States $v$. Nat'l City Lines. ${ }^{126}$ There both the trial and appellate courts followed recent vertical integration precedent even though exclusive supplying contracts, rather than integration, were under attack by the government. Defendants were indicated under Sections $I$ and 2 of the Sherman Act for conspiring to restrain and monopolize the trade in tires, petroleum products and busses between the city transit companies of operator defendants and the manufacturing companies of supplier defendants. Operator-defendants, a group of interlocking holding corporations for local transit companies, were treated primarily as a single group in the case. Supplier-defendants were five largely non-competitive ${ }^{\mathrm{T} 27}$ manufacturing corporations. The contractual arrangement consisted of a series of tenyear requirements contracts and in connection therewith, a series of investment contracts whereby the suppliers provided the operators with almost ten million dollars for buying up local transit companies. Although the contracts were negotiated separately, the suppliers were fully aware of each others' actions, and were shown to have consulted together about the arrangements. ${ }^{\mathrm{x} 2} \mathrm{~A}$ conviction under Section 2 of the Sherman Act was affirmed by the Seventh Circuit. ${ }^{\text {229 }}$

A requisite of the jury verdict in the City Lines case was a finding of specific ${ }^{226}$ I 86 F. 2d 562 (C.A. 7th, I95I), cert. denied 34I U.S. 916 (195I).

${ }_{227}$ Firestone Tire \& Rubber Co., General Motors Corp., Phillips Petroleum Co., Mack Manufacturing Corp., and Standard Oil Co. (Calif.). Mack and GM both made busses, although of different types. Their "division" of the City Lines market was not carried out and Mack dropped out of the plan three years before the indictment. Trans. Rec. at 569, 58I, 59960r, 797-99, 1062, United States v. Nat'l City Lines, I86 F. 2d 562 (C.A. 7th, I95I). Phillips and Standard Oil both sold petroleum products but were not in competition with each other since they operated almost entirely in different areas and did not have contracts covering the same City Lines subsidiaries. Tbid., at 883-84, I277-1 329 ; $1361-69$, I67 $15-75$.

${ }_{228}$ United States v. Nat'l City Lines, 186 F. 2d 562, 570-7I (C.A. 7th, 195I).

rag Ibid. 
intent. Although extensive market power was present at the levels "integrated," ${ }^{3_{30}}$ the horizontal power was treated as lawful and issues relevant to the second Paramount test were eliminated by the manner in which the indictment was framed and by the jury's verdict. The first count of the indictment charged defendants with conspiring to extend their ownership to new local transit companies. ${ }^{\mathrm{T} I}$ However, the defendants were acquitted on this charge; and the second count of the indictment, on which they were convicted, charged only a conspiracy to monopolize the trade between suppliers and operators without any allegation of present or attempted horizontal monopoly..$^{\mathrm{1} 2}$ As in the Yellow $C a b$ case, the possibility that vertical integration was being used to evade public regulation of operator defendants' transit lines was not considered. ${ }^{\mathrm{x} 3}$ Similarly, exclusion of evidence eliminated the test of the Columbia Steel case as to whether an unreasonable restraint actually resulted from defendants' activities. ${ }^{x 34}$ The language of the trial judge in excluding this evidence ${ }^{\mathrm{r} 35}$ and his charge to the jury ${ }^{136}$ leave no doubt that specific intent to restrain and monopolize trade to

${ }^{x 30}$ The operating companies were mostly local transit monopolies regulated as public utilities. On the supplier level, General Motors had previously been convicted as a single unit, for exercising illegal vertical control in a case condemning its practice of tying in financing with its cars, United States v. General Motors Corp., I2I F. 2d 376 (C.A. 7 th, I94 I), and in that case the Court of Appeals had emphasized the "dominant position" of General Motors "in the automobile industry." Ibid., at 403 . See text and notes at notes 97-98 supra.

${ }^{131}$ Trans. Rec. at 8-9, United States v. Nat'l City Lines, I86 F. 2d 562 (C.A. 7th, r95I).

${ }^{232} \mathrm{Tbid}$., at $\mathrm{r}_{3}-\mathrm{I} 8$. The government neither alleged nor proved any restraint or monopolization in any particular geographical or distributional market.

${ }^{233}$ In return for cheaper financing, the suppliers could have received higher prices for their products paid for by the operators' consumers from funds made available under local regulation because of the operators' inflated costs and rate bases. Operator defendants received over $\$_{9}, 000,000$ from the sale of stock, mostly preferred, to suppliers. Ibid., at I $445-48$. In previous financing arrangements, operator defendants had been forced to pay an underwriter's fee of $\$ 325,000$ to obtain $\$ 4,000,000$ in financing, and at the time of the first deal with the suppliers they had been unable to obtain other financing at all except at "prohibitive" prices. Tbid., at $46 \mathrm{I}-74$. That City Lines was getting a bargain is indicated in the following quotation from a letter by its counsel to Phillips, "You are buying the stock at $\$ 5 \circ$ a share, when the market, which is very thin, is about $\$ 40$ a share." Ibid., at 1234 .

There was however, no conclusive evidence as to the reasonableness of operator defendants' fares, rate bases or prices paid for supplies.

${ }^{134}$ Ibid., at 709-I6, 942-43, roo8-Ir. See Brief for Appellants at 3I-34, 68, 84-89, ibid.

${ }^{135}$ At one point District Judge Campbell explained his exclusionary rulings in the following language, Trans. Rec. at 7 I6, United States v. Nat'l City Lines, I86 F. 2d 562 (C.A. 7 th, 195I): "[W] here a complaint charges such an unreasonable restraint as the facts of the Yellow $\mathrm{Cab}$ case show, the amount of interstate trade affected is immaterial in determining whether a violation of the Sherman Act has been charged. A restraint may be unreasonable either because a restraint otherwise reasonable is accompanied with a specific intent to accomplish a forbidden restraint, or because it falls within the class of restraints that are illegal per se. Now, this case, on the charging part of the indictment falls within the first classification. The Government charges a specific intent to accomplish a forbidden restraint."

${ }^{3}{ }^{6}$ The following paragraphs were among the most important in the charge, ibid., at II76-77: "Likewise, if you find ... that any two or more of the defendants ... with deliberate intent agreed to monopolize that part of the interstate trade ... consisting of the sale of motor busses, petroleum products, tires and tubes, used by local transportation systems which National, 
the detriment of competitors was a necessary prerequisite to any verdict of guilty.

To find specific intent, it is necessary for the trier of fact to believe that the defendants' acts were accompanied with a certain wrongful state of mind going beyond the mere intent to commit the acts in question. ${ }^{137}$ This requirement could presumably be fulfilled by a showing that defendants consciously intended to violate the statute..$^{x 3^{8}}$ Defining specific intent solely in such terms would cripple the antitrust laws. Conscious wrongdoing may not co-exist with the most extreme form of economic restrictions, and intent to violate the law would be extremely hard to prove even when present. The requirement of "willful wrongdoing" has long been held inapplicable as a necessary test of illegality in the antitrust field. ${ }^{139}$ For the purposes of Sherman Act interpretation, specific intent may better be defined in terms of the particular practices forbidden, ${ }^{\mathrm{I} 4^{\circ}}$ and it is in this second sense that it must be used in the vertical forestalling field. The twin evils at which the antitrust laws are traditionally thought to be aimed are excluding competitors and tampering with prices. Vertical forestalling necessarily

American or Pacific owned, controlled, or had a substantial financial interest in, then you may find such defendants guilty under Count II of the indictment. . . .

"It is not unlawful to make a requirements contract, and it is not unlawful to make an investment of risk capital in the stock of a customer or potential customer for the purpose of producing a new market, nor is such an investment illegal merely because it is made with knowledge that other companies have made, or have been requested to make, similar investment, or with knowledge that negotiations are being carried on with other companies for such investments. In order for you to find any of the defendants guilty of the charges in this indictment, you must find that they participated in a conspiracy with specific intent to accomplish the single over-all unlawful purpose charged in the indictment. ...

"In order to find such a specific intent [it] is necessary to find ... that... defendants knowingly, willfully and deliberately intended to accomplish a forbidden restraint."

${ }_{337}$ Dangel, Criminal Law $\$ 54$ (195I); r Burdick, The Law of Crime § I20 (I946).

${ }^{1} 3^{8}$ Many cases hold that where a statute makes it a crime to conspire to commit acts not otherwise unlawful, criminal liability under that statute must rest on a finding of conscious wrongdoing. See cases cited in I5 C.J.S., Conspiracy $\S 45$ (I939); 3 Burdick, The Law of Crime $\S$ roor (1946); May, Law of Crimes $\S$ I28 (4th ed., Sears and Weihofen, I938). At present the prohibitions of the Sherman Act are broader than the old common law of restraints and monopolizations; see United States v. Socony-Vacuum Oil Co., 310 U.S. r $_{50}$, 225, n. 59 (1940). Compare United States v. Aluminum Co. of America, I48 F. 2d 4I6, 427-32 (C.A. 2d, 1944), with Standard Oil Co. of New Jersey, 221 U.S. I, 55-62 (19rI). And the Act covers activities not themselves criminal, or even civil wrongs under any federal statutes. Rahl, Conspiracy and the Anti-Trust Laws, 44 Ill. L. Rev. 743, 744-45 (I950). From this it is arguable that conscious wrongdoing should be a necessary part of conspiracy cases under the Sherman Act.

139 See United States v. General Electric Co., 80 F. Supp. 989, ro16 (S.D. N.Y., I948); O'Halloran v. American Sea Green Slate Co., 207 Fed. 187, I89 (N.D. N.Y., I9I3); United States v. American Naval Stores Co., I72 Fed. 455, 46I (S.D. Ga., Igog).

$x^{\circ}$ In most crimes involving a specific intent, the intent requirement is explicitly stated as an element in the crime and must simply be proved in the same manner as the other elements of the crime in question. Clark \& Marshall, The Law of Crimes $\$ 49$ (4th ed., Kearney, I940); Miller, Handbook of Criminal Law $\$$ I 7 (I934). Two difficulties arise under the Sherman Act. Besides the conscious wrongdoing problem in conspiracy cases, see text and note at note 
involves an intent to exclude competitors from the trade inter se. Hence, a definition in terms of exclusion, as indicated in the $A \& P$ case, might easily confuse intent to exclude inter se with the broader intent to exclude from the overall market; and at one point in the charge to the jury in the City Lines case this very confusion seems to have occurred. ${ }^{\mathrm{x} 4}$ The net effect of such confusion would be to erect a per se rule by making the intent that accompanies any vertical forestalling sufficient wrongful specific intent. A definition in terms of intent to achieve overall market control in order to raise prices, as suggested by $Y$ ellow $C a b I$, would be more in keeping with Columbia Steel's rejection of per se illegality.

Adoption of a broader intent requirement would give defendants an opportunity to justify their integration on the ground that it produced greater ef-

${ }_{13} 8$ supra, there is a problem created by the language of $\S \mathrm{I}$. Under $\S 2$, it is unlawful to "attempt... combine or conspire ... to monopolize"; the object of any unlawful intent is clear. But the $\$ \mathbf{I}$ wording is "contract, combination ... or conspiracy, in restraint of trade," not "contract, combination or conspiracy to restrain trade." The statute does not define the intent involved in agreements in restraint of trade. The courts have not faced this problem squarely. A comprehensive analysis of specific intent under $\S \mathrm{I}$ is lacking. However, in United States v. Columbia Steel Co., 334 U.S. 495, 520-27 (r948), Justice Reed repeatedly speaks of the "specific intent ... to accomplish an unreasonable restraint," indicating that the Court will treat the statute as though it read "contract, combination or conspiracy to restrain trade."

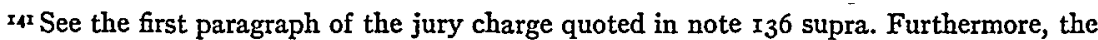
discussion of authorities relied on to support the charge gives evidence that Judge Campbell may possibly have felt that intent to exclude competition from the trade inter se was sufficient (when coupled with conspiracy, see text and notes at notes I47-60 infra) to sustain a finding of illegality. See Trans. Rec. at I 4 48-5o, United States v. Nat'l City Lines, I86 F. 2 d 562 (C.A. 7 th, I95I). The argument from the cases and quotations relied upon apparently runs as follows: The Sherman Act condemns all unreasonable restraints or monopolizations of interstate commerce no matter how small. United States v. Yellow Cab Co., 332 U.S. 218, 226-27 (I947). Such restraints may be unreasonable either because they are unreasonable per se or because they have an injurious effect on competition or because a specific intent is involved. United States v. Columbia Steel Co., 334 U.S. 495, 522, 524 (I948). Where an exclusive contract is involved the supplier gets a monopoly of the buyer's business. But only general intent need be shown to prove an intent to monopolize. United States v. Griffith, 334 U.S. 100 (I948). [The citation of the Griffith case and the following quotation relied on by the trial judge indicate how important the notion of general intent in monopolization cases was in his charge: "Section ...2 condemns the monopoly of 'any part' of trade or commerce. ... Second ... 'specific in tent' is not necessary to establish a 'purpose or intent' to create a monopoly but . . . the requisite 'purpose or intent' is present if monopoly results as a necessary consequence of what was done. ... [M]onopoly power, whether lawfully or unlawfully acquired, may violate Section 2 of the Sherman Act though it remains unexercised ... for ... the existence of the power 'to exclude competition when it is desired to do so' is itself a violation of Section 2, provided it is coupled with the purpose or intent to exercise that power." United States v. Paramount Pictures, 334 U.S. I3I, I73 (I948).] There is in the City Lines case an agreement which everyone intended to enter into and whose effects were an exclusion of competition from some portion of interstate commerce. That agreement was a conspiracy under the Act. From that the intent to monopolize which violates the Act can be inferred because its formation necessarily eliminated competition from the trade inter se so that intent to exclude will be inferred. This reasoning clearly stumbles into the pitfall of confusing intent to monopolize inter se with intent to monopolize the market, but the presence of many of the quotations and citations used by Judge Campbell is difficult to explain on any other hypothesis. 
ficiency or prevented the growth of monopoly at the integrated level. ${ }^{42}$ It must be remembered, however, that intent can generally be proved only by inference from defendants' activities rather than by direct proof. ${ }^{x / 3}$ In consequence, a specific intent case ( $Y$ ellow $C a b I I$ ) is, practically speaking, not greatly different from one involving the question of whether the restraints shown are so unlawful that intent may be inferred (Columbia Steel). ${ }^{\mathrm{x} 4}$ In both types of cases, the borderline between legality and illegality cannot be easily and precisely determined with the result that a great deal depends on the trier's findings of fact.

The position of the Court of Appeals in the City Lines case on the specific intent issue is ambiguous. At one point, the court appears to adopt the position that in executing requirements contracts the defendants "intentionally performed acts which inevitably led to violation of Section 2 of the statute." ${ }^{145}$ The violation which inevitably resulted, according to Circuit Judge Lindley, was exclusion of "competitors from a market composed of the City Lines defendants and their operating subsidiaries, present and future." ${ }^{146}$ As indicated above, this would mean that requirements contracts are illegal per se since the parties to them must intend to exclude competitors inter se. Such a conclusion would be quite inconsistent with the court's citation of authority (although quite consistent with the Standard Stations case) since neither Yellow Cab I nor Columbia Steel depend on per se rules, the former requiring a broader intent and the latter explicitly rejecting per se illegality in the vertical integration situation.

The discussion of intent may, however, be read as part of the court's analysis of conspiracy. ${ }^{147}$ Judge Lindley may have felt that the presence of conspiracy made the finding of the broader specific intent unnecessary. By the traditional criminal law definition, conspiracy is an agreement to do an unlawful

${ }^{142} \mathrm{~A}$ specific intent inference is ordinarily rebuttable so that defendants always have the privilege of introducing evidence showing their freedom from wrongful intent. Clark and Marshall, The Law of Crimes $\$ 49$ (4th ed., Kearney, r940); Miller, Handbook of Criminal $\mathrm{Law}$ of $\S \mathrm{I} 7$ (I934). The limits on the background material that might be logically relevant to such inquiries could be extremely broad. The fact that defendants are necessarily better informed about their own activities than the government (or other plaintifi) will generally give them an advantage in this type of case.

${ }^{243}$ See United States v. McHugh, 253 Fed. 224, 228 (W.D. Wash., I917); I Burdick, The Law of Crime I40 (x946); Dangel, Criminal Law 82 (I95I).

${ }^{144}$ The primary difference will be in the emphasis on personal motivation. For instance, in the City Lines case the trial judge restricted the amount of evidence on the economic background which defendants were permitted to bring in on the theory that intent was the main issue. See text and notes at notes I34 and I35 supra. At the same time the court allowed the broadest sweep to evidence on the life history and personal motives of the principal individual defendant. Trans. Rec. at $444-45$, United States v. Nat'l City Lines, 186 F. $2 d 562$ (C.A. $7^{\text {th }}$, 195 $\mathrm{r}$ ).

I45 United States v. Nat'l City Lines, I86 F. 2d 562, 57 I (C.A. 7 th, I95I).

$x_{16}^{6}$ Ibid.

${ }^{247} \mathrm{~A}$ major part of the opinion was devoted to the conspiracy question. Ibid., at 569-7x. The intent discussion occurs at the end of the conspiracy analysis, and it is not clear whether intent is being considered as an element in the conspiracy or as a separate requirement. Tbid., at 57 r. 
act or to do a lawful act by unlawful means. ${ }^{148}$ To be sufficiently "unlawful" to form the basis of a conspiracy, the ends or means must either be known by the conspirators to be unlawful or else so antisocial in nature that knowledge of their illegality can be presumed. ${ }^{49}$ Thus a finding of conspiracy normally subsumes a finding of "corrupt" intent, ${ }^{x 50}$ and, by using this definition, Judge Iindley would arguably be justified in holding that his conspiracy finding brought the case within the intent requirements of Yellow Cab and Columbia Steel.

However, conspiracy in the antitrust field is not used in the criminal law sense. Originally all acts which would produce restraints or monopolizations of trade may have been thought of as being so antisocial that any commission thereof would justify an inference of wrongful specific intent. ${ }^{\mathrm{TSI}}$ That is no longer

${ }^{2} 4^{8}$ Pettibone v. United States, I48 U.S. I97. (1893); Duplex Co. v. Deering, 254 U.S. 433 (I921); 3 Burdick, The Law of Crime $\$ \$ 984,994$ (I946).

${ }^{4} 9$ Criminal Conspiracy: Specific Intent as an Element of the Crime, 38 Harv. L. Rev. 96 (I924). Clark and Marshall, The Law of Crimes $\$$ I26 (4th ed., Kearney, I940). There has been much dispute about this definition of "unlawfulness" in conspiracy. In the case of statutory prohibitions like the Sherman Act which make it criminal to conspire to commit acts not otherwise unlawful, the tendency is toward stricter requirements. In fact, some cases would require actual conscious wrongdoing. See discussion in note 138 supra.

${ }^{\text {r5० }}$ The joint object of the conspirators should be distinguished from the individual intent of each conspirator to become a party to the agreement. Harno, Intent in Criminal Conspiracy, 89 U. of Pa.L. Rev. 624, 63 I (r94I). It is the joint intent that must be corrupt, general criminal intent presumably sufficing for the individual intent to join. See The Conspiracy Dilemma: Prosecution of Group Crime or Protection of Individual Defendants, 62 Harv. L. Rev. 276, 280-8I (r948). Prof. Burdick states that where the object of a conspiracy is criminal the general criminal intent that can be inferred from the doing of the acts in question is all that need be shown even for the joint intent. 3 Burdick, The Law of Crime $\$$ I00I (1946). But where, as in the antitrust field, the object is not criminal in and of itself the vast majority of cases hold that "corrupt intent" is prerequisite to the existence of a conspiracy. Harno, supra.

${ }^{\text {ISI }}$ The following quotation illustrates the attitude of many of those who debated the Sherman Act in Congress. "When Robin Hood undertook to rob his fellow citizens he took his life in his hand and with at least some sort of courage took the consequences of his crimes, but these modern foot-pads have not the grace of his courage, but commit their robberies by stealth." Sen. James Jones, opening debate on Sen. Sherman's bill in the second session of the 5 oth Congress. 20 Cong. Rec. 1458 (1889). It was not the hot heads who carried the day, however. Under the guidance of Sen. Hoar, the second House-Senate Conference Committee turned the bill into a restatement of the common law rules against monopoly and restraint of trade, albeit with much more drastic remedies attached. Hamilton and Till, Antitrust in Action, United States Temporary Nat'lEconomic Committee, Monograph No. 16 at 5 - I I (r940). Even Sen. Sherman, who felt that his original bill was declarative of the common law, spoke of the combinations at which it was aimed as "monsters," governed by the "law of selfishness,"who exercised "a kingly prerogative, inconsistent with our form of government,"and who "should be punished as criminals." 2I Cong. Rec. $2456-62$ (I8go). Chief Justice White, also interpreting the Sherman Act in the light of the common law, thought that restraints of trade became unlawful only when they were so unreasonable as to "give rise to the presumption of an intent to injure others" or "to do wrong to the general public." Standard Oil Co. (N.J.) v. United States, 22I U.S. I, 52, 58 ( $\mathrm{Ig} \mathrm{II}$ ), and he emphasized the presence of wrongful intent in his analysis of the facts in the Standard Oil case. Tbid., at 75-77. For other early cases emphasizing the wrongful motives or methods of Sherman Act defendants consult: Swift \& Co. v. United States, Ig6 U.S. 375, 396 (Ig05); United States v. American Naval Stores Co., I 72 Fed. 455, 458-59 (S.D. Ga., I909). 
true. Now the line between legality and illegality is recognized as being a difficult one to draw, ${ }^{152}$ and violators are not as often thought of in the moralistic terms of an earlier period. ${ }^{x 33}$ The failure to apply the more stringent criminal penalties provided in the Sherman Act, viz., heavy personal fines and jail sentences, is perhaps the best indication of this shift in attitude. ${ }^{154}$ Nevertheless, when a court decides that certain joint activities result in restraints or monopolizations it will find an unlawful conspiracy without much consideration of the intent involved. General intent to commit the acts in question suffices. ${ }^{155}$ Conspiracy is defined merely in terms of agreement, and even the definition of agreement has been considerably attenuated so that the phrase "concert of action" probably defines the present antitrust definition of conspiracy fairly

${ }^{152}$ Hamilton and Till, op. cit. supra note 151 (passim).

${ }_{253}$ "Nor is the legality of the combination complained of to be determined by innocence of motives; the prohibition of the statute may not be evaded by good intentions. The legislation is deciarative of economic policy, violation of which is deemed detrimental to common welfare, irrespective of motive or other wrongful intent." Prairie Farmer Pub. Co. v. Indiana Farmer's G. Pub. Co., 88 F. 2 d 979, 982 (C.A. 7 th, I 937). "[E]very defendant . . . was aware of the plan, consciously participated in it, and must be held to have violated the law. . . [U] sually a violation of the Sherman Act is not an ordinary crime. Violation is ordinarily an economic offense, the seriousness of which is not related to the moral turpitude of the offender." United States v. New York Great A \& P Tea Co., 67 F. Supp. 626, 679 (N.D. Ill., I946). See United States v. Aluminum Co. of America, I48 F. 2d 4r6, 429-32 (C.A. 2d, I944); Hearings on Sen. Res. 4I before the Senate Committee on Civil Service 625-68, especially 629, 664-65, 80th Cong. Ist Sess. (r947) (Testimony of Wendell Berge).

${ }^{354}$ See Hamilton and Till, op. cit. supra note $\mathrm{I} 5 \mathrm{I}$, at 78-8I, I21-25.

${ }^{255}$ In United States v. Patten, 226 U.S. 525, 543 (Igr3), the Court stated: "[We] regard it as altogether plain that by its necessary operation [the conspiracy] would directly and materially impede and burden the due course of trade and commerce among the states.... And that there is no allegation of a specific intent to restrain such trade or commerce does not make against this conclusion, for, as is shown by prior decisions of this court, the conspirators must be held to have intended the necessary and direct consequences of their acts and cannot be heard to say the contrary." Similar language may be found in other Section I cases. See, e.g., United States v. Masonite Corp., 316 U.S. 265, 275 (I942); United States v. General Motors Corp., I2I F. 2d 376, 406 (C.A. 7th, I94I). A similar tendency to disregard specific intent is to be found in Section 2 cases. See United States v. Griffith, 334 U.S. 100, 105 (1948); United States v. Paramount Pictures, 334 U.S. r3r, I73 (r948). Such disregard has even been combined with repeated emphasis on conspiracy as an essential basis of the illegality. American Tobacco Co. v. United States, 328 U.S. 78I (I946).

An authority on the criminal law has outlined the factors normally present when a legislature erectscriminalpenalties for certain behavior regardless of the mental element involved. "In statutory crime ... it is frequently unnecessary to show more than that the accused committed the act forbidden by the statute.... [T] where (I) the penalty incurred is not great, but (2) the damage caused to the public by the offense is in comparison with the penalty, very great; and where (3) the offense is such that there would be peculiar difficulty in obtaining adequate evidence of the ordinary mens rea." Kenny, Outlines of Criminal Law 44 (rsth ed., Phillips, 1936). The latter two of these factors, if not always the first, are present in the antitrust field with respect to showing corrupt intent in conspiracy cases. Perhaps the courts feel that the presence of these factors justifies reducing the intent requirement in Sherman Act conspiracies to a requirement merely of general criminal intent just as the same factors justify the dropping of even the general intent requirement elsewhere. Cf. The Conspiracy Dilemma: Prosecution of Group Crime or Protection of Individual Defendants, 62 Harv. L. Rev. 276, 28r (I948). 
accurately. ${ }^{\mathrm{r} 56}$ Under the Sherman Act, express agreement need not be shown ${ }^{\text {;57 }}$ and action by individuals with the knowledge that others are participating in a plan the success of which depends on joint action is conspiratorial..$^{{ }^{8} 8}$ Some cases have even been interpreted as showing a trend toward holding that the parallel action of oligopolistic firms too large to ignore each other's actions is an illegal conspiracy. ${ }^{\mathrm{s} 9}$ This emphasis on the "agreement" aspect of conspiracy in current antitrust cases makes it impossible for a conspiracy finding to supply any specific intent requirement. In fact, as the preceding paragraph shows, Judge Lindley's own discussion of intent requires no more than the intent to monopolize inter se which is present in all vertical forestalling cases. ${ }^{160}$ Thus if the presence of conspiracy is a sufficient support for the holding in the City Lines case, the specific intent requirement has, in effect, been washed out and replaced by concert of action as a basis of vertical forestalling illegality.

The handling of intent and conspiracy in the City Lines case is, then, a long step toward per se illegality for all vertical forestalling. The analysis of intent could lead directly to a per se rule. Even assuming that the conspiracy finding is essential, ${ }^{16 x}$ the flat ban may not be far removed. As already noted, conspiracy

${ }^{156}$ See e.g., United States v. United States Gypsum Co., 333 U.S. 364,394 (I948); American Tobacco Co. v. United States, I47 F. 2d 93, I07 (C.A. 6th, 1944). Nor is the tendency to use a broad definition of agreement in conspiracy actions confined to the antitrust field. Consult Cousens, Agreement as an Element in Conspiracy, 23 Va. I. Rev. 898 (1937).

157 United States v. Masonite Corp., 316 U.S. 265 (1942); Eastern States Lumber Ass'n v. United States, 234 U.S. 600 (I9I4).

${ }^{158}$ Interstate Circuit, Inc. v. United States, 306 U.S. 208 (I939).

${ }^{259}$ E.g., United States v. Paramount Pictures, 334 U.S. I3I (I948); American Tobacco Co. v. United States, I47 F. 2d 93 (C.A. 6th, r944), aff'd 328 U.S. 78 I (r946). In these cases a large amount of the evidence consisted of showing parallel actions by supposed competitors, and some commentators have argued that they are precedent for the statement that proof of control of an industry by an alleged conspiracy together with proof of the non-competitive (viz., parallel) behavior of the conspirators is sufficient evidence of a Sherman Act violation. Rostow, The New Sherman Act: A Positive Instrument of Progress, I4 Univ. Chi. L. Rev. 567, 586-87 (r947); Adelman, Effective Competition and the Antitrust Laws, 6r Harv. L. Rev. I289, $\mathrm{r}_{324-27}$ (1948). However, there was considerable evidence of actual agreement in the Tobacco and Paramount cases and the Adelman-Rostow position is far from being universally accepted. Johnson and Stevens, Monopoly or Monopolization-A Reply to Prof. Rostow, 44 Ill. L. Rev. 269, 292-96 (1949); Dession, The Trial of Economic and Technological Issues of Fact: I, 58 Yale L.J. roI9 (I949).

160 See text and notes at notes 145 and 146 supra.

${ }^{36 x}$ The importance of the conspiracy issue in Judge Campbell's view of the case is indicated by the following quotation from the charge to the jury, Trans. Rec. at $1175-76$, United States v. Nat'l City Lines, I86 F. 2 d 562 (C.A. 7 th, I95I):

"The essence of the crime charged ... is the illegal agreement, conspiracy, and combination. . . . [T] he crime of which the defendants are charged is committed when and if the agreement to achieve the illegal purposes charged in each Count is reached, and it is immaterial whether or not the agreement is later carried out. The success or failure of the combination or conspiracy charged in each Count of the indictment is likewise immaterial ... if you find beyond a reasonable doubt that any two or more of the defendants entered into the conspiracy or combination as charged in these Counts of the indictment....

"However, the making of an investment of each supplier defendant in the preferred and common stock of National, American and Pacific, was not in itself unlawful, nor was the 
as used in the antitrust field means only concert of action; its intent side has been dropped. ${ }^{162}$ Thus, stating that a conspiracy to forestall vertically is unlawful, although vertical forestalling without more is permissible, is to say that vertical forestalling is all right done unilaterally but may not be done by joint action. ${ }^{163}$ Such a rule would parallel other areas of antitrust law doctrine in which the single trader may do what the "loose combination" may not. ${ }^{.64}$ In fact, the Sherman Act is worded largely in terms of joint action, ${ }^{165}$ probably for the reason that its framers thought of restraints of trade primarily in terms of group activities. ${ }^{166}$ Penalizing groups for doing what a single individual may lawfully do has been justified because of the increased power flowing from joint action, the added determination each conspirator receives from knowing that he has the support of confederates, and the increased contemporary importance of organized forms of crime. ${ }^{167}$ Suspicion of group action in the economic sphere

execution of the several supplier requirements contracts in itself unlawful, whether or not made in connection with the investment... unless you further find, beyond a reasonable doubt, that such investments and sales contracts were a part of, or resulted from a conspiracy among the defendants or some two or more of them to effect a forbidden restraint in commerce in motor busses, petroleum products, tires and tubes."

${ }^{162}$ The loose use of conspiracy in the antitrust field has created a threat of dangerous extensions of criminal liability in other fields. See Justice Jackson concurring in Krulewitch v. United States, 336 U.S. 440, 445, 45I-52 (r 949 ); The Conspiracy Dilemma: Prosecution of Group Crime or Protection of Individual Defendants, 62 Harv. L. Rev. 276, $281-82$ (1948).

${ }^{163}$ A rule against joint vertical control where such control exercised unilaterally is permissible already exists in the patent-agency field. See text and note at note 83 supra. The same thing will be true of boycotting if a flat per se rule develops for group boycotts while unilateral boycotts remain illegal only when pursued by concerns with market dominating power. See text and notes at notes 84-93 supra.

${ }^{164}$ Perhaps the most graphic example is the contrast between certain Section 2 monopoly cases, e.g., United States v. United States Steel Corp., 25I U.S. 4I7 (I920), and the trade association cases, e.g., American Column \& Lumber Co. v. United States, 257 U.S. 377 (1921). United States Steel could fix prices and set production quotas for the one-half of the nation's steel producing facilities owned by it; but suggestions of future prices and production limitations by the American Hardwood Manufacturer's Association to its members (producers of one-third of the nation's hardwood) was unlawful. See Jaffe and Tobriner, The Legality of Price Fixing Agreements, 45 Harv. L. Rev. 1164 (I932).

${ }^{165}$ The means enumerated in Section I for accomplishing unlawful restraints (contracts, combinations and conspiracies) all require the action of more than one person; and it was more than fifty years after the passage of the Act before any single firm was found to be illegal under the "monopolization" wording of Section 2. Rahl, Conspiracy and the Anti-Trust Laws, 44 Ill. L. Rev. $743,747-48$ (1950).

${ }^{266}$ Ibid., at 744-48. In the words of Chief Justice White, the primary evil toward the eradication of which the Sherman Act was aimed was "the enormous development of corporate organization, the facility for combination which such organizations afforded, the fact that the facility was being used and that combinations known as trusts were being multiplied...." Standard Oil Co. (N.J.) v. United States, 22 I U.S. r, 50 (rgIr). White felt that monopolization by an individual was not one of the matters covered by the Act. Tbid., at 55-62.

167 Miller, Flandbook of Criminal Law $\$ 32$ (I934); The Conspiracy Dilemma: Prosecution of Group Crime or Protection of Individual Defendants, 62 Harv. L. Rev. 276, 283-84 (1948); Criminal Conspiracy: Bearing of Overt Acts upon the Nature of the Crime, 37 Harv. L. Rev. II2I, II23 (I924). 
is at least as old as Adam Smith's famous remark to the effect that "People of the same trade seldom meet together, even for merriment and diversion, but the conversation ends in a conspiracy against the public, or in some contrivance to raise prices." 68 Apparently the feeling is that supposedly independent competitors should act independently, and that when they do not, but instead come together to affect trade conditions, a purpose and a power to restrain or monopolize trade will be presumed even though the joint activities in question are not clear restraints or monopolizations on their face. Such a presumption may be justified where those combining are direct competitors. In the City Lines case, however, there was no agreement among competitors since the supplier defendants were not in competition with each other and the operator defendants were treated as a single unit. The presumption of unlawful power and purpose is considerably attenuated although perhaps still justified with respect to such a "conspiracy." "r69 But the City Lines case goes further still. The charge to the jury called for the finding of a conspiracy if any two or more of the defendants agreed to set up exclusive supplying arrangements. ${ }^{170}$ That could mean one supplier and one operator defendant. Such a definition would mean that all vertical forestalling by agreement between two independent firms is conspiratorial. Moreover, since conspiracy may be found within a single firm, ${ }^{17 x}$ vertical integration or single trader boycotts could also be the result of a "conspiracy." In these situations, neither the original "intent" basis nor the antitrust "combination of competitors" basis for making conspiracy the foundation of illegality exists. But these attenuated uses of conspiracy are current in antitrust cases, as the rationale of the concept appears to be forgotten, so that possible conspiracy limitations of the City Lines case may be largely meaningless.

In summary, vertical forestalling is clearly illegal when combined with unlawful monopoly power. Some of the "loose" forms of vertical control are apparently illegal per se, and others may be illegal even though connected with monopoly power not unlawful under the antitrust laws as now interpreted. If the City Lines case is not restricted to its facts (as it could be since it is in a field of per se illegality under the Standard Stations case) the use of intent and conspiracy may greatly broaden the areas of per se illegality, especially in the "close" vertical forestalling area. Although the courts have not as yet applied

\footnotetext{
${ }^{168}$ Quoted in Adelman, Effective Competition and the Antitrust Laws, 6I Harv. L. Rev. I289, I322 (I948).

${ }^{\text {I69 }}$ See United States v. Line Material Co., 333 U.S. 287, $3^{\text {II }}$ (I948).

${ }^{170}$ See the paragraphs of the charge quoted in note $16 \mathrm{I}$ supra.

${ }^{27}$ No antitrust case to date has found a conspiracy within a single, unitary corporation; but corporations have been held to have conspired with their wholly owned subsidiaries and dicta indicate that the day of single corporation conspiracies may not be far off. Kramer, Concerted Action Between a Corporation and its Officers-A Violation of the Sherman Act? II Fed. Bar J. I30 (I95I); Are Two or More Persons Necessary to Have a Conspiracy Under Section I of the Sherman Act?, 43 Ill. L. Rev. 55I (I948).
} 
these broad rules in situations not involving monopoly power, there is as yet no indication of what the limits of illegality will be in the vertical forestalling field. ${ }^{172}$ Prerequisite to both an evaluation and prognosis of the trend of vertical forestalling rules is an analysis of its economic consequences.

\section{IV}

Vertical control without more has little if any adverse effect on free competition. ${ }^{273}$ In fact, the extension of vertical control can have strong monopoly-

172 The "appreciable segment" test will apparently not serve as a significant limit. The City Lines case fully supports the previous interpretation of the appreciable segment test as a mere jurisdictional or "de minimis" requirement probably synonymous with the "substantial share" test of the "loose" vertical forestalling cases. Supplier-defendants argued that they did not come within the scope of the test since they were charged only with monopolizing the trade of one customer, and they urged that the test required the finding of a restraint or monopolization having geographical or distributive significance. Reply Brief for Appellants at I5-30, United States v. Nat'l City Lines, I 86 F. 2d 562 (C.A. 7 th, I95I). There was joinder on this point as the government interpreted the test to mean only that a substantial volume of trade was involved. Brief for the Appellee at 28-30. Relying on the Yellow Cab case, the Court of Appeals specifically rejected defendants' theory, thus impliedly approving the government's argument. Ibid., I86 F. 2d $562,5^{66-68 . ~}$

I73 Stocking and Watkins, Monopoly and Free Enterprise 298-99, 314-30, 360-61 (I95I); Edwards, Maintaining Competition 98, 176-77 (r949); Miller, Unfair Competition r94-213 (I94x); Adelman, Integration and Antitrust Policy, 63 Harv. L. Rev. 27 (I949); Hale, Vertical Integration, 49 Col. L. Rev. 92 (r949), and authorities cited.

A more difficult question is presented in gauging the efficiency of various types of vertical control, especially vertical integration. Vertical integration may be inefficient because it entails planned exchanges not subject to market checks, because of the increased complexities in management it necessitates, because the optimum size of plants may be different on the separate levels integrated, because shifts in technology make formerly efficient patterns of integration unworkable, and because vertically integrated firms are slow in their adjustment to technological changes. Stigler, The Theory of Price 2ro (I949); Wallace, Market Control in the Aluminum Industry I77-79 (I937); Burns, The Decline of Competition 431-33, 436 (1936); Dennison, Vertical Integration and the Iron and Steel Industry, 49 Econ. J. 244, 249-54 (r939); Jewkes, Factors in Industrial Integration, 44 Q. J. Econ. 621, 626-29, 635-37 (I930); Lavington, Technical Influences on Vertical Integration, 7 Economica 27, 29-30 (1927). Resale price maintenance can create inefficiency in distribution by depriving low-cost distributors of the advantage of their superior efficiency, and also, on the manufacturing level by fostering trivial differentiation of products and irrational choice of goods by consumers, Stocking and Watkins, supra, at 330 .

But vertical integration can also be a means for greater efficiency. In many cases there are technological savings from operating successive stages of production together. Or, vertical integration may promote cheaper production because integrated firms have less overhead per unit of output (especially since intracorporate selling and advertising expenses are eliminated), have a steadier flow of materials better attuned to their own particular needs, have access to cheaper investment capital due to their greater size and stability, and are able to locate plants most advantageously. Wallace, supra, at 182-88; Burns, supra, at 433-34; Adelman, The A \& P Case: A Study in Applied Economic Theory, 63 Q. J. Econ. 238, 247 (1949); Frank, The Significance of Industrial Integration, 33 J. Pol. Econ. I79 (Ig25). Similarly, requirement contracts may protect against price fluctuations, assure supplies, avoid storage costs, save selling expenses and make financing easier. Stockhausen, The Commercial and Anti-Trust Aspects of Term Requirements Contracts, 23 N.Y.U.L.Q. Rev. 4 I2 (I948). Whatever the relative importance of these various factors, a careful weighing of them is not central to antitrust analysis. Competition is the arbiter of efficiency. The purpose of the antitrust laws is to provide a framework in which effective competition may operate, not to prejudge the verdict of the market place as to the relative merits of varying modes of production. 
lessening results in situations where one level of an industry is monopolized and others are not. In such situations the competitive firms, not wanting to pay monopoly prices and desiring to share in monopoly profits, will extend their operations to the monopoly level so that the horizontal monopoly control is weakened. ${ }^{774}$ Various arguments against this position have been advanced. The "double profit" argument-to the effect that vertically integrated firms can undersell their competitors because they derive profits from several levels rather than just one ${ }^{\mathrm{x} 75}$ - has long been thoroughly discredited. ${ }^{776}$ Another complaint against vertical control is that it cuts off the one-level firms from access to raw materials and markets. It is argued that in boom times vertically integrated firms have easier access to scarce raw materials than their non-integrated rivals, and similarly that the assured outlets of the integrated unit will be valuable assets in a depression. However, both of these advantages will obtain only where the integrated firms control a disproportionate share of the outlets and suppliers, because, if they do not, the non-integrated outlets and suppliers will serve the non-integrated manufacturers to the same extent that the integrated firms serve themselves. Moreover, even if the integrated firms do control a disproportionate share of outlets and suppliers, in boom times non-integrated firms can dispose of all their goods without the trouble and expense of maintaining a selling organization which will lose money during bad times; and during a depression, only the non-integrated firms will be in a position to take full advantage of the over-supply of raw materials. ${ }^{177}$ Thus the advantages and disadvantages of vertical control in having outlets and suppliers assured will probably largely cancel out as against the single level firm. ${ }^{.78}$

${ }^{74}$ Burns, The Decline of Competition 421-23 (1936); Stockhausen, The Commercial and Antitrust Aspects of Term Requirements Contracts, 23 N.Y.U.L.Q. Rev. 4I2, 426-27 (I948); Stigler, The Extent and Bases of Monopoly, 32 Amer. Econ. Rev., Supp. No. 2, at I, 22 (1942); Jewkes, Factors in Industrial Integration, 44 Q.J. Econ. 621, 629-30 (I930).

${ }^{175}$ See Frank, The Significance of Industrial Integration, 33 J. Pol. Econ. 179, r9o (r925).

${ }^{176}$ The integrated firm must obtain a reasonable return on each level of production in order to justify its investment. Any advantage it derives from being able to forego profits on prior levels of production in order to undersell competition at the final selling stage will mean an abnomally low rate of return on its total investment. Integrated firms might be able to stand such a low rate of return, but, if so, it would only be because of factors not related to vertical integration such as undistributed surpluses from former years, derivation of monopoly profits elsewhere or size large enough to withstand temporary losses. Burns, The Decline of Competition 437-38 (I936); MacGregor, Industrial Combination 97-98 (Ig06); Adelman, Integration and Antitrust Policy, 63 Harv. L. Rev. 27 (I949). Cf. Thorp, The Integration of Industrial Operation $255^{-58}\left(\mathrm{Ig}_{24}\right)$; Willoughby, The Integration of Industry in the United States, I6 Q.J. Econ. 94, Ix2 (Igor). But cf. Stigler, The Theory of Price 209 (I949).

${ }^{177}$ See Jewkes, Factors in Industrial Integration, 44 Q. J. Econ. 62I, 63I-33 (I930). But see Dennison, Vertical Integration and the Iron and Steel Industry, 49 Econ. Jour. 244, 255-56 (I939).

${ }^{178}$ Stigler, The Theory of Price 210 (I949); Hale, Vertical Integration, 49 Col. L. Rev. 92I, 947 (I949). 
A more telling argument against vertical control is that vertical forestalling restricts the possibilities for entry of new firms since more capital is required to enter an industry with large integrated units than one where each level of production is separate. ${ }^{179}$ This argument does not apply to industries where only small percentages of the firms are integrated, but where an important number of firms in an industry integrate vertically the markets open to competitors are reduced, and the tendency is to force everyone to integrate..$^{80}$ Therefore, vertical forestalling may increase the amount of capital required for entry in a given industry. However, if an industry offers opportunities for good profits and there is no artificial scarcity of investment capital this difficulty hardly seems a justification for condemning all vertical control.

The tendency of the courts, especially in the integration cases, to condemn vertical forestalling more easily in connection with all forms of monopoly rests on a sound economic basis. In combination with horizontal power, vertical forestalling provides a method of exploiting and extending horizontal monopoly power. On the exploitation side, many monopolists can achieve the greater monopoly profits due to price discrimination ${ }^{\mathrm{x} 8 \mathrm{r}}$ by vertical forestalling. Where demand for a monopolized article varies directly with the frequency of use of another product the monopolist can charge more to the customers with the greater demand by tying in the unmonopolized product with the monopolized article and charging a high price for the former. ${ }^{82}$ This may be the only way certain monopolists can exact monopoly profits. Suppose a monopolist controls a product used extensively by a few buyers who will pay more than numerous buyers who use the product less frequently. If the cost conditions are such that total cost will approximately equal total revenue whether the monopolist produces a few units selling at the high price or the many units at the low price (due to the economies of scale), then large scale production combined with tie-in price discrimination will provide the only means of achieving monopoly profits. ${ }^{28_{3}}$ Similarly, a single producer of a product having several uses with varying demand conditions for each may find vertical integration the only means available for price discriminating so as to take full advantage of the differing demands. ${ }^{184} \mathrm{~A}$ kind of price discrimination may be an explanation of

${ }^{279}$ Miller, Unfair Competition 212 (194r). Cf. Vertical Integration in Aluminum: A Bar to "Effective Competition," 60 Yale L.J. 294, 30I-5 (r951).

${ }^{280}$ Hale, Vertical Integration, 49 Col. L. Rev. 921,949 (I949).

${ }^{28 x}$ Stigler, The Theory of Price 223-27 (I949).

${ }^{83}$ Cf. Judson L. Thomson Mfg. Co. v. FTC, I50 F. 2d 952, 954 (C.A. Ist, 1945).

${ }^{28}{ }_{3}$ Cf. B. B. Chemical Co. v. Ellis, 314 U.S. 495,498 (I942).

${ }_{184}$ Where $A$ has a monopoly of product $P$ which is made into products $X$ and $Y$, if the producers of $X$ can afford to pay more for $P$ than can the producers of $Y, A$ will want to price discriminate. However, this may not be possible as long as the producers of $Y$ can sell to the producers of $\mathrm{X}$. But if $\mathrm{A}$ takes over the production of $\mathrm{Y}$ it can then discriminate by charging a low price to itself as the producer of $Y$ and a higher price to the producers of $X$ without fear 
the "squeeze" behavior of some integrated monopolies. ${ }^{185}$ In all these situations, however, horizontal power is the basic evil, vertical control being only a method for fully exploiting the monopoly power. Nevertheless outlawing vertical control may make it difficult for the monopolist to exact any significant monopoly profit. And where the monopoly power exploited is either publicly sanctioned as in the case of patents, or too small to fall within the present interpretation of Section 2, a prohibition against vertical forestalling provides one of the few restraints which may be imposed on the exercise of such power. ${ }^{186}$

A second general area of monopoly exploitation via vertical forestalling occurs in the field of publicly sanctioned monopolies. ${ }^{187}$ Public utilities having monopolies on two or more levels may use vertical agreements to avoid the full impact of rate regulation where the different levels are under the jurisdiction of

of cross sales. Even where cross sales are not a problem, a manufacturer operating under conditions of imperfect competition may be prohibited from price discrimination by the RobinsonPatman Act, 49 Stat. I526 (1936), I5 U.S.C.A. $\$ \S$ I3, 2Ia (I95I), or the recent cases outlawing basing point systems, Triangle Conduit \& Cable Co. v. FTC, I68 F. 2 d I75 (C.A. 7 th, I948), aff'd by an equally divided court sub nom. Clayton Mark \& Co. v. FTC, 336 U.S. 956 (r949); FTC v. Cement Institute, 333 U.S. 683 (I948). Integration with the buyers from which the higher prices can be obtained provides a method of continuing the discrimination in such situations. Cf. United States v. Columbia Steel Co., 334 U.S. 495 (I948).

${ }^{185}$ Suppose $\mathrm{P}$ is the sole producer of raw material $\mathrm{X}$ and has a subsidiary $\mathrm{S}$ which, together with firms $T$ and $U$, has monopoly control of the manufacturing of the products into which $X$ is manufactured. In setting its price to $S, T$ and $U, P$ will equalize marginal revenue with marginal cost and its price will include a monopoly profit for itself. Similarly, when deciding at what price $S$ is to sell, $P$ will want to equalize $S$ 's marginal revenue with its marginal cost. But the marginal cost of $X$ as far as $P$ and $S$ are concerned will not be the price set for sales to the entire S-T-U market since $P$ is charging a monopoly price. Therefore, S's marginal cost will be less than that of $T$ and $U$ and $S^{\prime}$ 's sale price will be less than that at which $T$ and $U$ would normally expect to sell because of the lower cost figure used by S. Thus P's actions in setting prices as any monopolist normally would will have the effect of "squeezing" $T$ and $U$ even though $P$ is not consciously attempting to drive $T$ and $U$ out of business, but only trying to maximize profits.

${ }^{886}$ In the patent field, the Supreme Court has exhibited a strong tendency to limit the methods by which a legally sanctioned monopoly may be exploited through the use of vertical control devices, such as resale price maintenance and tying contracts. Schuller, The New Antitrust Illegality Per Se: Forestalling and Patent Misuse, 50 Col. L. Rev. 170, I84-95 (1950); Patent Abuses and Antitrust: The Per Se Rule, 64 Harv. L. Rev. 626 (I95I). The Court has referred to these techniques of vertical control in terms of extension rather than exploitation of the patent monopoly. See Automatic Radio Mfg. Co. v. Hazeltine Research, 339 U.S. 827, 832, 837-39 (r950); Mercoid Corp. v. Mid-Continent Co., 320 U.S. 66I, 666 (r944); Boston Store v. American Graphophone Co., 246 U.S. 8, 23 (rgI8). In this comment such techniques are referred to as "exploitation," with the word "extension" being reserved for situations where the monopolist uses his power to achieve monopoly on a second level. The strong language in United States v. General Electric Co., 272 U.S. 476, 489-9o (Ig26), supporting a patentee's right to use any "normal and reasonable" methods for securing his full "pecuniary reward" may explain the Court's preference for the use of the world "extension" rather than "exploitation" in cases limiting the scope of the patent grant.

${ }^{187}$ See Edwards, Maintaining Competition 97-98 (1949); Adelman, Integration and Antitrust Policy, 63 Harv. L. Rev. 27, 43-44 (I949); Hale, Vertical Integration, 49 Col. L. Rev. 921, 938-39 (r949). 
different regulatory bodies or some levels are not regulated at all. The practical difficulties inherent in allocating costs between the various levels of an integrated enterprise ${ }^{\mathrm{x} 88}$ make the task of the regulatory body extremely difficult even assuming that it can bring together the records of the company from every level. ${ }^{189}$ Where only one level is fully monopolized, as in the Yellow Cab case, the regulators could obtain competitive comparisons on cost figures, but where both consumer and supplier are monopolies, this check is lacking; and a rule banning vertical forestalling in such situations might well be justified..$^{190}$

The reasons for the use of vertical forestalling to extend monopoly power in situations not affording increased efficiency or the benefits of price discrimination are less important and the dangers to a competitive economy from such use of vertical forestalling are not as great. In certain situations there can be no doubt that vertical control may be used to extend monopoly power, primarily where such control is used as a defense against monopoly at the integrated level. Where a monopoly (or a competitive firm as previously explained) on one level is confronted with actual monopoly on a second level, there will be a tendency to use vertical forestalling to avoid paying high prices to the monopolists on the second level. ${ }^{\text {Igx }}$ In that situation, the vertical forestalling tends to break down monopoly on the second level unless the first monopolist achieves monopoly power on both levels. Even if a two-level monopoly is eventually achieved, the deterrent to new competitors presented by the necessity of making a larger initial investment in order to begin competing may be offset by the fact that the double monopoly will probably tend to have a lower price and greater production than if the two levels were separately owned.rgz In these situations, then, the net effect is to bring two monopolistic levels under joint control, a result which will normally not raise prices or increase the total power of the monopoly in the economy.

In a limited number of situations, horizontal monopolists might also desire to extend their vertical control for reasons other than as a defense against other monopolies. A monopolist may desire to expand his sphere of control in order to insulate himself by pushing prospective competitors farther afield and forcing

${ }^{188}$ Adelman, op. cit. supra note 187 , at $30-31$; Hale, op. cit. supra note 187 , at $941-45$. This difficulty also obtains for the integrated enterprise, of course, making it hard for any such enterprise to know how much it actually benefits (or loses) from being integrated.

${ }^{89} 9$ Edwards, Maintaining Competition 99, n. I2 (r949).

390 Cf. ibid., at I29-30, 177 .

291 Even the fear of future development of monopoly on the second level could be sufficient reason for a monopolist to integrate. Such fears might be especially strong in any area where the importance of patents could make future monopolies on other levels extremely powerful.

${ }^{192}$ Where a single monopolist controls two levels of an industry, when he decides that a decrease in price will increase his total revenue, he will immediately lower the price and pass the decrease long to the public. But where the two levels are separated, one monopolist will hesitate to decrease his price in any circumstances because he cannot be sure what action will be taken by the other monopolist (who may simply absorb the price reduction for his own benefit and not pass it along). See Marshall, Industry and Trade 430 (4th ed., I9z3). 
them to make a larger initial investment in order to compete. This reason may be of increased significance where there is a possibility that patent development might solidify the newly acquired levels. ${ }^{\mathrm{x} 3}$ Barring the existence of possible new patent monopolies or restrictions in the supply of capital, it is difficult to understand how a monopolist could greatly enhance his power to stifle new. competition by means of such vertical extension. The vertical extension would bring increased size, but whatever antitrust problems are raised by size alone are not aggravated because they are a product of vertical forestalling. More effective control of horizontal monopoly (and size) would render vertical extension in these situations harmless and would in fact remove the main reason for such extension, namely the desire to obtain protection against other horizontal monopolies.

\section{$\mathrm{V}$}

In the light of this economic analysis it becomes possible to appraise the courts' handling of vertical forestalling. Where connected with illegal monopoly, vertical forestalling is clearly illegal whether it involves monopolization of new levels, actual or attempted, or is only "closely related" to the original illegal horizontal combination and a "definite means" of carrying it out.194 In these situations, the courts have not analyzed the extent to which vertical forestalling injures the competitive structure. Cases where the expansion may be a means of exploitation or an attempt to bolster the original unlawful monopoly are not distinguished from cases where the expansion is an attempt to break down monopoly on other levels or merely an investment of surplus funds giving no added leverage other than that which results from increased size. One reason for this may be that under current relief notions the "fruits" as well as the "tools" of illegal monopoly power may be dissevered. ${ }^{95}$ Thus even economically harmless vertical forestalling may be cut off or enjoined if it was acquired as a result of the exercise of unlazeful monopoly power.

A few cases indicate that there is a limit past which the courts will not go. If the vertical control is clearly carried on for technological efficiency or as an innocent investment and has no connection with the illegal monopoly power, it may survive the dissolution of the monopoly. ${ }^{196}$ The net result is that a find-

${ }^{993}$ Cf. United States v. United Shoe Mach. Co., 247 U.S. 32 (I918).

194 United States v. Paramount Pictures, 85 F. Supp. 88r, 893-94 (S.D. N.Y., 1949).

${ }_{295}$ United States v. Crescent Amusement Co., 323 U.S. I73, I89 (1944); Schine Theatres v. United States, 334 U.S. xIO, I28-29 (r948); United States v. Paramount Pictures, 334 U.S. I3I, I 52-53 (I948).

${ }^{296}$ United States v. Aluminum Co. of America, I $^{8} 8$ F. 2d ${ }_{4}{ }^{16}$ (C.A. 2d, 1945), 91 F. Supp. 333 (S.D. N.Y., r950).

In the Paramount case, Justice Douglas states that some vertical integration entered into merely as "innocent investments" is permissible. "If in such cases the acquisition was not improperly used in furtherance of the conspiracy, its retention by defendants would be justified absent a finding that no monopoly resulted. And in those instances permission might be given the defendants to acquire the interests of the independents on a showing by them ... that neither monopoly nor unreasonable restraint of trade ... would result." United States v. Paramount Pictures, 334 U.S. I3I, 153 (1948). 
ing of illegal horizontal monopoly may make most vertical control unlawful with the burden being on the monopolist to show that the vertical control had no connection with the illegal monopoly if such control is not to be condemned.

Where vertical forestalling is attacked in situations involving lawful monopoly power under the antitrust laws as presently interpreted, more difficult problems arise. There may still be monopoly power sufficient to be more fully exploited or even extended by means of vertical forestalling. The fact that there will be no possibility of attacking vertical forestalling as a "tool" or "fruit" of illegal monopoly makes a direct attack on the vertical control necessary if it is to be removed; and the removal is, if anything, more important than in the case of illegal monopoly because of the impossibility of direct attack on the monopoly itself. But, following the economic analysis previously presented, the rules banning vertical forestalling must not be so broad as to ban such forestalling where it is not connected with monopoly power of any sort.

Traditional analysis of restraints and monopolizations of trade have been in terms of illegal power, purpose or effect. An "effect" analysis might look either to the effect on prices or the effect on competitors. Where the vertical forestalling is used as a price discrimination technique, it may not be too difficult to show an effect on prices. However, in many situations, as the Yellow Cab case shows, proof of effect on prices would be extremely difficult. The courts in the vertical forestalling cases have taken the other approach to the effect problem and treated exclusion as the major effect to be expected from vertical forestalling. Following the Columbia Steel case, the test of illegality in vertical forestalling cases would be whether an unreasonable amount of competition had been excluded. The determination of unreasonableness is often a long, difficult process whose results are uncertain, and, as Columbia Steel indicates, unlikely to result in banning vertical forestalling in all monopolistic situations.

Reliance on the "purpose" aspect of the traditional trichotomy is likely to prove equally unproductive. The City Lines case shows how easily the intent analysis may degenerate into an overly broad per se rule. On the other hand, if intent is restricted to the broader definition intimated in Yellow Cab I, the same difficulty of proof arises as with the "reasonableness of effect" test. Defendants will be permitted to justify their actions as intended to affect only a small part of the market, thus raising the same economic issues that would have to be resolved by the trier on the rule of reason analysis. The only difference would be an extra step in the reasoning process. Instead of weighing the many economic variables in terms of their market effect, the trier would consider them as factors bearing on the intent of the defendants. Once again the result would be an extremely general rule, uncertain of application in a particular situation, leaving much to the factual determination of the trier, and having no necessary relation to the question of the presence of monopoly which should be the touchstone of any rule of illegality for vertical forestalling.

The most direct test for the illegality of vertical forestalling would be a power 
test: the forestalling would be illegal when connected with monopoly power, in the economist's sense, but not otherwise. This test would, of course, require a different definition of monopoly power than that used in current Sherman Act cases. Judge Hand's " $30-60-90$ " dictum ${ }^{197}$ would have to be replaced for vertical forestalling cases by his earlier suggestion that a monopolist is one whose size relative to the market is such that he can affect price by a change in his output. ${ }^{\text {.98 }}$ Such a test would entail difficult problems of application but it would have the merit of putting the emphasis in vertical forestalling cases where it properly belongs. The present vertical forestalling rules have reached results equivalent to those which would be reached under this test in most cases. But the notions of conspiracy, intent and per se illegality that operated to achieve this are so broad that they set no proper limits on the scope of illegality other than the unguided horse sense of prosecutors and triers of fact in antitrust cases. The test suggested as a substitute for these several rules would not only introduce proper limits, it would also unify them into a single rule covering all the vertical forestalling situations. Per se illegality in fields, such as resale price maintenance, group boycotts and patent tie-ins, where monopoly power universally co-exists with vertical control would be an economic corollary of the "power" rule.x99

The present scattered rules concerning vertical forestalling could thus be

297 United States v. Aluminum Co. of America, I48 F. 2d 4I6, 424 (C.A. 2d, I945).

${ }^{998}$ United States v. Corn Products Refining Co., 234 Fed. 964, ror2 (S.D. N.Y., 1916).

${ }^{199}$ See text and notes at notes 88 and I05-II2 supra. A patent "is at least prima facie evidence of [market] control." Standard Oil Co. (Calif.) v. United States, 337 U.S. 293, 307 (I949). There are few who will argue that the per se rule should be extended uniformly to all vertical forestalling fields. In fact, such an extension would cause tremendous dislocation of long established business practices that have little relation to monopolies or restraints of trade and may increase efficiency. See note 173 supra for a discussion of the possible advantages to be derived from exclusive supplying contracts and vertical integration. Agency arrangements are enough like these two forms of vertical control so that the same reasoning will apply to them.

Unilateral boycotting, viz., refusal to deal by a single competitor, has never been thought to need justification in our system of free enterprise and can hardly be said to have adverse economic consequences when engaged in by a single firm in a competitive market. Similarly, tying arrangements are not bad when separated from monopoly power. See note 94 supra. Few will object to tying laces in with the new pair of shoes; and the often beneficial exclusive dealing contracts are in a sense tie-ins. (Each unit used during the operation of the contract is "tied-in" with all the rest.) Where the tie-in is desirable from the purchaser's point of view or where alternative combinations of products are close substitutes for the products in question, the tie-ins will not have restrictive effects on competition. It is only where a competitive product is tied-in with a monopolized product in situations where no alternative combination is available that the tying has adverse economic effects as a method of price discrimination by the monopolist. It has even been argued that the use of a tie-in is justifiable in the patent monopoly situation to facilitate the best possible operation of the patented product. See Int'l Business Machines Corp. v. United States, 298 U.S. I3I, I34 (I936). However, this argument does not bear close scrutiny. If the patented product operated better in connection with the tied-in product of the patentee, as against the goods of other makers of the tied-in product, the coercion of the tie-in would not be necessary. Ibid., at $138-39$. 
greatly simplified. A broad condemnation of vertical forestalling where it is employed to expend or exploit horizontal power capable of affecting market price would encompass all situations in which vertical control has direct adverse economic consequences. Such an interpretation actually harmonizes vertical forestalling precedent while at the same time confining dangerously broad language.

Perhaps the vertical forestalling cases are a symptom of unduly narrow interpretations of the antitrust laws. The courts may be struggling to restrict the monopolies they are unable to outlaw directly by denying them the opportunity to grow through the use of vertical control. In only very rare situations will the prohibition against vertical control effectively curb monopoly power. If and when the antitrust laws are amended or reinterpreted so as to become effective weapons against horizontal monopoly power, it is likely that the present broad rules concerning vertical forestalling will fall into disuse and oblivion. 